\title{
ABANDONO AFETIVO INVERSO: O ABANDONO DO IDOSO E A VIOLAÇÃO DO DEVER DE CUIDADO POR PARTE DA PROLE
}

\author{
ABANDONMENT REVERSE AFFECTIVE: ABANDONMENT OF THE ELDERLY AND \\ BREACH OF DUTY OF CARE BY THE OFFSPRING
}

\begin{abstract}
Cláudia Mara de Almeida Rabelo Viegas *
Marília Ferreira de Barros ${ }^{* *}$
\end{abstract}

\begin{abstract}
RESUMO: Cuida-se o presente artigo da análise acerca do Abandono Afetivo Inverso e a violação do dever de cuidado por parte dos filhos, situação cada vez mais recorrente pelo mundo, que tem gerado a vitimização dos idosos tanto no âmbito físico, quanto emocional. Não obstante o afeto seja a mola propulsora das relações familiares, certo é que o idoso ainda tem sido vítima de abandono afetivo pela própria prole. Pretende-se, por meio do procedimento indutivo, investigativo bibliográfico e uma abordagem discursiva, chamar a atenção não somente dos filhos que se utilizam desta prática nefasta, mas de toda a família sobre a importância do dever de cuidado, como fonte de melhor qualidade de vida do idoso. Temse por motivação minimizar o sofrimento do idoso não pelo intermédio da prestação pecuniária, mas pela conscientização dos próprios filhos, pois, embora amar não seja obrigatório, cuidar é um dever constitucional que não pode ser descurado.
\end{abstract}

PALAVRAS-CHAVE: Abandono Afetivo Inverso. Dever de Cuidado. Direito dos Idosos. Afeto.
ABSTRACT: Take care to this article analysis about the Reverse Affective Abandonment Affective and breach of duty of care by the children, a situation increasingly recurrent in the world, which has generated the victimization of the elderly both in the physical realm, and emotional. Despite the affection is the mainspring of family relationships, it is certain that the elderly still have been a victim of emotional abandonment by the offspring. It is intended by the inductive procedure, bibliographic investigative and a discursive approach, calling attention not only of the children who use this nefarious practice, but the whole family about the importance of the duty of care as a source of better quality life of the elderly. It has been a motivation to minimize the suffering of the elderly not by means of the cash benefit, but the awareness of their children, for although love is not required, care is a constitutional duty that cannot be overlooked.

KEYWORDS: Reverse Affective Abandonment. Duty of Care. Elderly rights. Affection.

SUMÁRIO: Introdução. $1 \mathrm{O}$ Envelhecimento Humano Paralelo à Evolução Histórica do Idoso. 2 O Conceito de Idoso. 3 O Aumento Populacional de Idosos no Cenário Mundial. 4 A Legislação Afeta ao Direito do Idoso. 4.1 A Constituição da República de 1988 e o Idoso. 4.2 O Código Civil Brasileiro (Lei 10.406, 10 de janeiro de 2002) e o Idoso. 4.3 O Estatuto do Idoso (Lei $\mathrm{n}^{\circ} 10.741,1^{\circ}$ de outubro de 2003). 4.4 A Lei Orgânica da Assistência Social (Lei no 8.742, 07 de dezembro de 1993). 4.5 A Política Nacional do Idoso (Lei ${ }^{\circ}$ 8.842, 04 de janeiro de 1994). 5 As Obrigações dos Filhos em Face dos Pais Idosos. 5.1 O Abandono. 5.2 O Afeto. 6 Responsabilidade Civil: Breves Considerações. 7 O Dano Moral no Contexto do Abandono Afetivo Inverso. Considerações Finais. Referências.

\section{INTRODUÇÃO}

Em decorrência do aumento do número de idosos, nas últimas décadas, o envelhecimento tem despertado a atenção do direito, notadamente, para os problemas que a terceira idade vem tentando superar. Não rara é a situação de decadência, maus tratos e abandono que centenas de idosos vêm passando no Brasil.

\footnotetext{
* Doutora em Direito pela Pontifícia Universidade Católica de Minas Gerais (PUC Minas). Professora dos Programas de Pós-Graduação em Direito da Pontifícia Universidade Católica de Minas Gerais (PUC Minas) e da Fundação Mineira de Educação e Cultura (FUMEC), Minas Gerais. Coordenadora do curso de Direito da Faculdade Del Rey, Minas Gerais.

${ }^{* * *}$ Bacharel em Direito pela Pontifícia Universidade Católica de Minas Gerais (PUC Minas).
} 


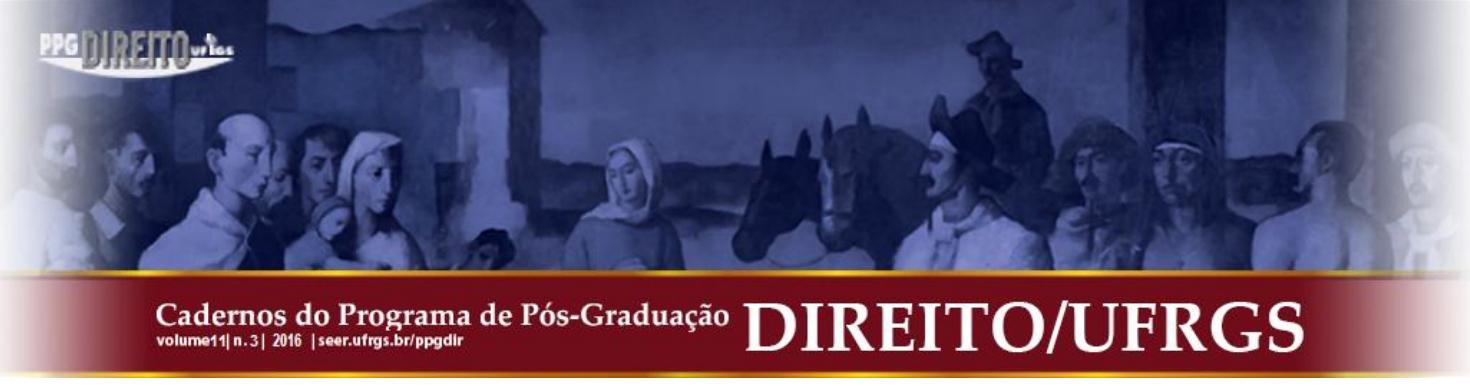

As famílias, cada vez mais, têm sido dilaceradas por inimizades e relacionamentos nulos. Não há dúvidas de que a falta de afeição por outra pessoa pode ocorrer, havendo grau de parentesco ou não, todavia, o respeito recíproco é um dever. Os membros da família têm o dever de cuidar do bem-estar do idoso.

Nos termos dos artigos 229 e 230 da Constituição da República de 1988, os filhos maiores têm o dever de ajudar e amparar os pais na velhice, carência ou enfermidade; como também de defender sua dignidade e bem estar, garantindo-lhe o direito à vida, reconhecendo ser seu dever, bem como da sociedade e do Estado. O dever de cuidado com o idoso também se encontra disposto no artigo 98 da Lei 10.741/03. Trata-se, portanto, de obrigação, e não de faculdade.

Conquanto o dever de cuidado dos filhos para com os genitores idosos seja regulamentado por lei, há também o dever moral e afetivo, que não tem sido respeitado, gerando os transtornos psíquicos e agravamento de doenças.

Exatamente, deste enfrentamento surge à figura jurídica do Abandono Afetivo Inverso, em que idosos abandonados afetivamente pelos seus próprios filhos, teriam direito à reparação por danos morais. Embora o afeto seja considerado, por muitos, como impossível de ser exigido, tem sido objeto de responsabilização civil pelo não cumprimento do dever de cuidado.

Vive-se em uma sociedade capitalista, em que as pessoas se preocupam a priori com a questão financeira, e, nesse contexto, por meio de análise bibliográfica e jurisprudencial, quer se analisar o dever de indenizar dos filhos, em face do Abandono Afetivo Inverso.

\section{O ENVELHECIMENTO HUMANO PARALELO À EVOLUÇÃO HISTÓRICA DO IDOSO}

O processo de envelhecimento é um fenômeno histórico e inevitável, afinal, vem desde a essência da humanidade cercado de concepções, mitos, verdades crenças e medos, alternando, portanto, de cultura em cultura o que vem a ser a "velhice". Spirduso $(2005$, p. 06) define velhice como sendo um "processo ou conjunto de processos que ocorrem em organismos vivos atinge de forma geral a todas as pessoas, seja de direta ou indiretamente".

Para se refletir sobre o processo de envelhecimento, faz-se necessário, principalmente, analisar a relação deste com a sociedade, uma vez que o sujeito se constitui ao longo de sua 


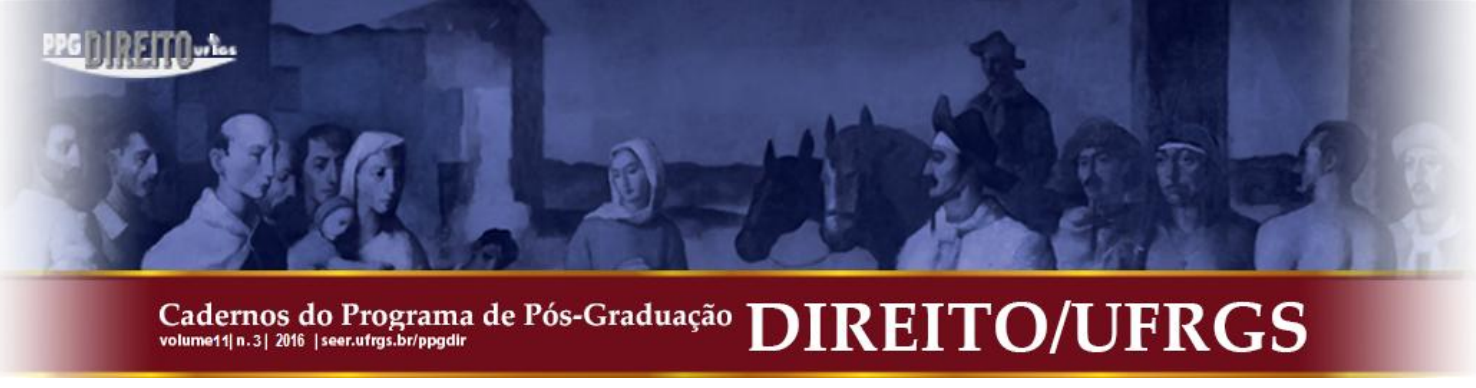

vida inserido no meio social. Afinal, cada etapa da vida possui um componente social diferente, influenciando o indivíduo a moldar-se em função das transformações decorrentes de cada período do desenvolvimento humano. (ALVES; MOREIRA; NOGUEIRA, 2013).

Ficam demonstradas diferentes visões, desde os povos primitivos, em que critérios biológicos, sociais e psicológicos referentes ao envelhecimento, são encarados por uns de forma a preservar a vida do idoso e por outros, através de um extremo desinteresse. Segundo Fernandes (1997):

O antropólogo americano Leo Simmons, na obra "O Papel do Idoso na Sociedade Primitiva" (The Role of the Aged in Primitive Society), menciona que era habitual os mais velhos receberem os melhores pedaços da caça, serem servidos antes de todos, com grande respeito às suas incapacidades e limitações, mormente no tocante à alimentação e enfermidades que causavam dependências. (FERNANDES, 1997, p. 30)

Nas sociedades Orientais, principalmente China e Japão

[...] o ancião era visto com uma aura de privilégio sobrenatural que lhe concedia uma vida longeva e como resultado, este ocupava um lugar primordial, onde a longevidade se associava com a sabedoria e a experiência. (RODRIGUES, 2001, p. 149-158).

Nas culturas Incas e Astecas, a população anciã era tratada com muita consideração. A atenção a esta população era vista como responsabilidade pública.

Os antigos Hebreus também se destacavam pela importância que davam a seus anciões, que, em épocas de nomadismo eram considerados os chefes naturais dos povos que eram consultados quando necessário. Na cultura hebraica encontramos Matusalém que era considerado como se tivesse vivido 969 anos. (RODRIGUES, 2001, p. 149-158).

Infelizmente, nem todas as sociedades demonstravam interesse na manutenção da vida do idoso, fato bem destacado por Moreno (2007), in verbis:

O desprezo por parte dos primitivos, como os poncas, os esquimós, os tupis, as tribos sul-africanas, entre outros culminavam na matança dos idosos. Os próprios filhos matavam os pais por um costume ou por determinação legal. É muito conhecida a história do mawle sagrado, uma espécie de clava chata, com a qual os filhos golpeavam os pais, na cabeça, ao atingirem a idade de 70 anos. Na Islândia, em época de penúria, decidiu-se, em deliberação solene, que todos os idosos e improdutivos fossem mortos. Esta determinação fazia parte do sistema legal, que protegia a sociedade contra os membros supérfluos e dependentes. Os gregos e romanos nutriam profundo desprezo pelos velhos. Todos os povos admiradores da força física valorizavam a mocidade e desprezavam a velhice. Na Lapônia, extremo norte da Escandinávia, o idoso era considerado um problema. Era costume arraigado entre as gerações de esquimó ser o ancião abandonado em um trenó para acabar 


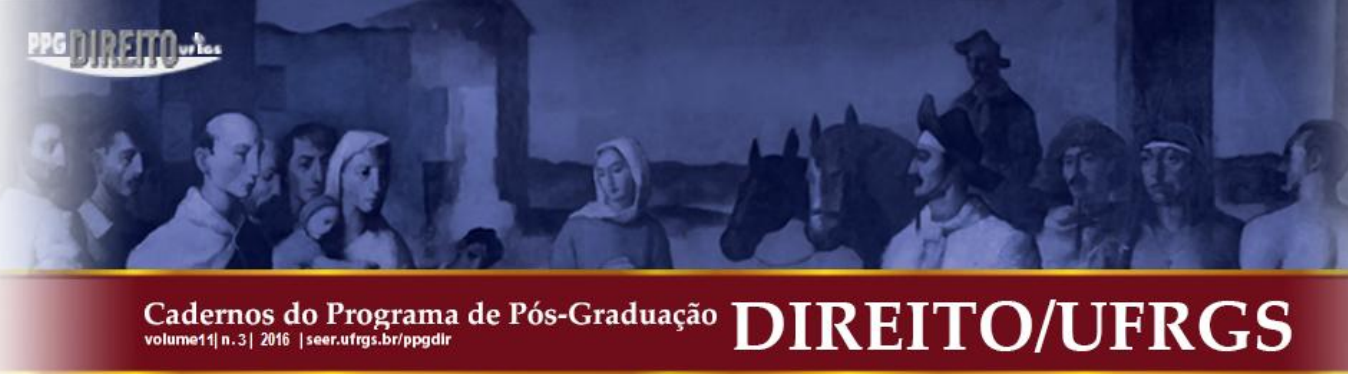

\begin{abstract}
morto e devorado por lobos ferozes que povoavam aquelas terras gelados. O idoso era deixado ali com todos os seus pertences para morrer. Entre os dinkas, povo que habitava a parte meridional do Sudão, era tradição enterrar vivo o velho para que ele passasse a eternidade ainda no vigor de suas forças e imune à decrepitude. A mesma crença tinham os habitantes das ilhas Fidji, os quais levavam seus velhos à morte violenta para assegurar-lhes uma existência vigorosa, pois acreditavam que iam ressuscitar no outro mundo. (MORENO, 2007, p. 4-5)
\end{abstract}

Em Roma, a visão contrária à velhice foi vencida, por Cícero, romano, filósofo e político, ao inovar com a obra De Senectude (Saber Envelhecer) (PRAZERES, 2008).

$\mathrm{Na}$ etapa do cristianismo, a velhice deixou de ser um tema recorrente, a Igreja Católica passou a taxar o idoso como ser frágil, um problema social expressivo e declinado. Do século V ao XVII houve um "lapso temporal" quanto à visão específica da inserção social e econômica do idoso perante a sociedade, na qual, ainda prevalecia a hesitação, desrespeito e descrença em relação à velhice. (BOUCINHAS, 2016).

Fazendo uma permuta para o século XVIII, as transformações advindas da Europa com a Revolução Industrial, permitiram avanços científicos, não só na área da fisiologia como da anatomia, possibilitando descartar várias suposições que giravam em torno da velhice. Todavia, não foram suficientes para melhorar a situação dos idosos, que em função da Revolução Industrial, se encontravam sem trabalho e submetidos à miséria. (LEMOS et al., 2016).

No início do século XIX, em 1804, Napoleão Bonaparte chegou ao poder, fazendo vigorar em 21 de março do mesmo ano, o Código Napoleônico que contemplou os idosos, além de se tornar inspiração para demais Constituições e o Código Civil de 2016. (PINTO, 2016).

Entretanto, durante essa transição século XVIII e XIX, a Europa se viu diante de avanços da medicina, em que resultou na diminuição dos índices de mortalidade, e consequentemente, favoreceu a manutenção da longevidade. Impossível não ressaltar o ano de 1889, em que foi instituído na Alemanha pelo Chanceler Bismark, o direito a aposentadoria dos idosos, fato que se estendeu a outros países. Dando existência ao Estado-Previdência (ARAÚJO, 2016).

Após a Segunda Guerra Mundial, o cenário tanto político, econômico e social passa a ser outro perante os idosos, o século XX prestigia a gerontologia e a geriatria, permitindo uma vida mais digna e de melhor inserção na sociedade além da possibilidade de trabalhos essenciais. (BOUCINHAS, 2016). Advindo em 1848, a Declaração dos Direitos Humanos, 


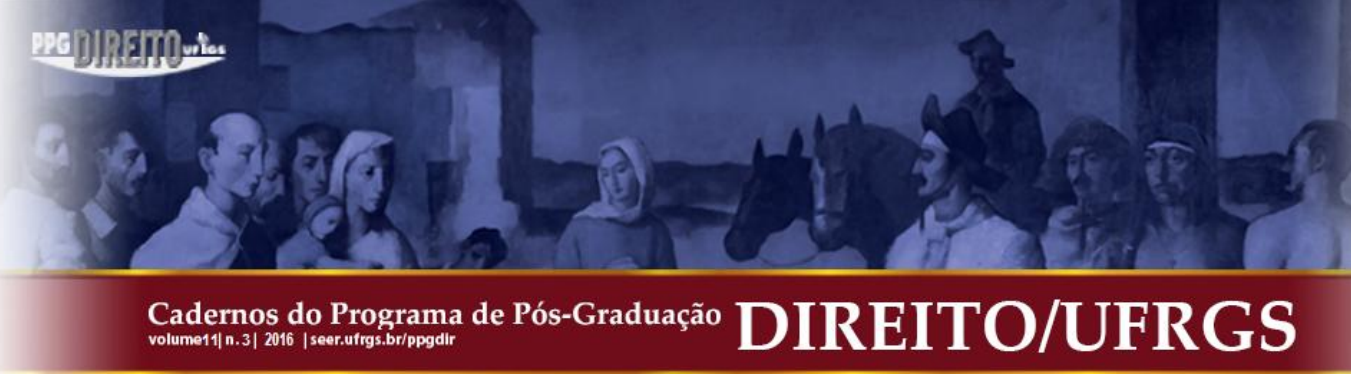

atentando para a atuação do Estado perante a velhice, documento legal e marco para os dias atuais.

O que se percebe após a análise dos períodos supramencionados, é que o idoso passou por períodos conturbados, desde aceitação até a negação do fenômeno que virou o crescimento populacional dos idosos.

Sendo assim, o envelhecimento é um processo multifatorial, não havendo uma padronização do seu estabelecimento. Contudo, observa-se a existência de pressão social para a adoção de um modelo comportamental a ser seguido, nas mais variadas fases da vida. As regras sociais impõem os comportamentos "adequados" para crianças, adolescentes, adultos e idosos, que integram o tempo social imposto desde o nascimento, em que se evidencia uma espécie de padrão determinante quanto a circunstâncias da vida, a exemplo de idade para o ingresso na escola, a inserção no mercado de trabalho, o casamento, a constituição de uma família e a aposentadoria. (SCHNEIDER; IRIGARAY, 2008).

\section{O CONCEITO DE IDOSO}

O Estatuto do Idoso, Lei $\mathrm{n}^{\mathrm{o}} 10.741$, de $1^{\mathrm{o}}$ de outubro de 2003, define que: "Idoso é toda pessoa com idade igual ou superior a 60 (sessenta) anos”. (BRASIL, 2003). Entretanto, a Organização Mundial da Saúde OMS (2002) entende que idosa é aquela pessoa com 60 anos ou mais, em países em desenvolvimento, e com 65 anos ou mais em países desenvolvidos.

Embora explanados os conceitos do termo idoso, difícil determinar ao certo o idoso apenas em função de sua faixa etária, sobretudo, levando em conta que o envelhecer é uma característica individual de cada pessoa. As condições biológicas estão interligadas à idade cronológica, existindo, portanto, outros fatores que contribuem para a velhice. Notam-se, na sociedade, diferenças significativas em relação à saúde, participação e independência entre pessoas do mesmo grupo etário. De fato, pode ocorrer um desequilíbrio harmônico entre todo o conjunto orgânico em ritmo mais acelerado, por uma série de fatores biológicos e sociais.

Infelizmente, o termo idoso muitas vezes é utilizado em conotações negativas, tais como "velho", "decadente", "antigo" atribuídas pela sociedade contemporânea marcada por tabus de juventude, beleza e dentre outros estereótipos, ante envelhecimento. O exercício de apenas atribuir nomenclaturas e ainda de forma leiga aos idosos, faz grande parte da população esquecer que a idade não é sinônimo de capacidade e sim de amadurecimento, 


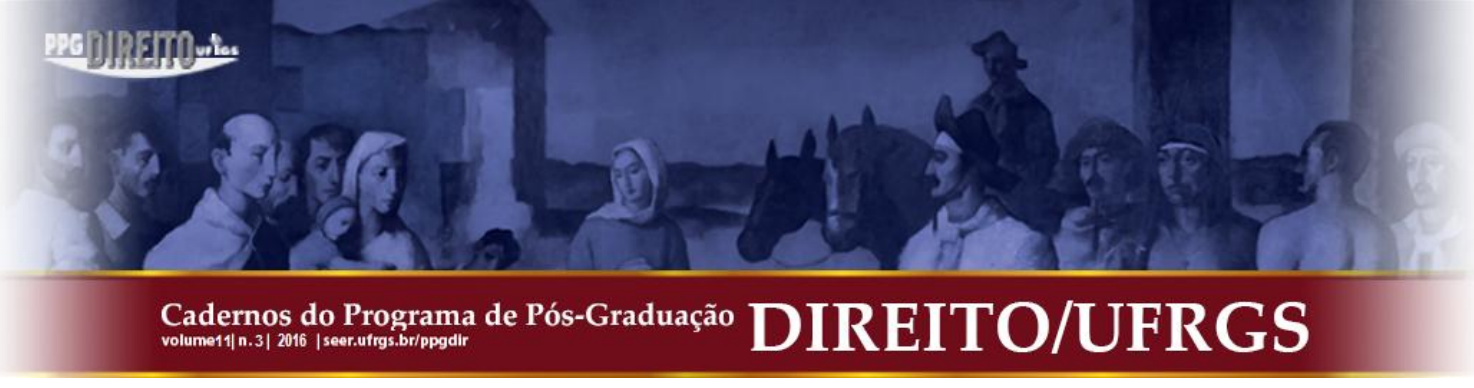

experiências que podem ser compartilhadas com os "mais jovens", que se julgam mais ativos e perspicazes.

É claro que, nessa fase da vida, o corpo necessita de mais cuidados, carinho e amor. Segundo Norberto Bobbio citado por Braga (2011):

O cronológico define como idoso a pessoa que tem mais idade do que um certo limite preestabelecido. Por se tratar de um critério objetivo, de facílima verificação concreta, geralmente é adotado pelas legislações, como, por exemplo, a que trata da aposentadoria por idade... Pelo critério psicobiológico deve-se buscar uma avaliação individualizada da pessoa, ou seja, seu condicionamento psicológico e fisiológico, logo, importante não é a sua faixa etária, mas sim as condições físicas em que está o seu organismo e as condições psíquicas de sua mente... O critério econômico-social considera como fator prioritário e fundamental, uma visão abrangente do patamar social e econômico da pessoa, partindo-se sempre da ideia de que o hipossuficiente precisa de maior proteção se comparado ao auto suficiente. (BOBBIO apud BRAGA, 2011, p. 3).

Enfim, ninguém está excluído de "ser idoso", o tempo é inevitável, o idoso é a porta do passado que leva ao futuro.

\section{O AUMENTO POPULACIONAL DE IDOSOS NO CENÁRIO MUNDIAL}

A crescente longevidade está cada vez mais presente no cenário mundial, porém só envelhecer não basta, é necessário preencher todos esses anos de vida, com acesso á saúde, educação, lazer e todos os direitos inerentes aos idosos. Infelizmente, esse pensamento não é extensivo a toda cultura social, muitos acreditam que o idoso é um atraso ao desenvolvimento sócio-econômico.

Esse fenômeno que virou o crescimento populacional dos idosos atinge, principalmente, os países da Europa e América do Norte, dos quais existem lugares de predominância de uma população de faixa etária mais alta.

Há 600 milhões de pessoas com mais de 60 anos no planeta, afirma o subsecretário de Promoção Humana da Secretaria Especial de Direitos Humanos (SEDH), Perly Cipriano, citando dados da Organização das Nações Unidas (ONU). Eles já formam um contingente nada desprezível, que representa cerca de $10 \%$ dos habitantes da Terra. O envelhecimento populacional é um fenômeno mundial. Significa que há um crescimento mais elevado da população idosa do que dos demais grupos etários. Esse aumento é produto de uma das maiores conquistas sociais do século $\mathrm{XX}$, que foi o maior acesso popular às tecnologias e aos serviços de saúde. Isso fez com que a esperança de vida dos brasileiros aumentasse cerca de dez anos, entre 1980 e 2000, atingindo 71 anos, em média, no início do século XXI. (NERY, 2007). 
Embora essa notícia seja considerada benéfica em função de indicar que a expectativa de vida está aumentando em termos globais, paralelo a esse aumento vem à preocupação, de que é necessário que os países se preparem para receber esse contingente de idosos que está se formando.

O envelhecimento, antes de tudo, tem que ser ativo e saudável. Não faz sentido apenas se vangloriar da expansão da longevidade, sem políticas específicas e eficazes para a manutenção da mesma ao longo de mais anos. Esse crescimento não se restringe apenas a países desenvolvidos como grande parte da população pensa. "Em 2050, haverá 2 mil milhões de pessoas idosas no mundo, e $80 \%$ delas viverão em países que atualmente classificamos como emergentes ou em desenvolvimento." (GAMA, 2013).

Inegável é a emergente necessidade de mudança principalmente na área de saúde e sustentabilidade, que envolve os idosos. Afinal, é um momento da vida que se houvesse um atendimento efetivo das necessidades em tais áreas, aí sim o envelhecimento ativo da população idosa, seria realmente maior. Para Lenharo "a medicina convencional atribui a cada diagnóstico um tratamento. Não é incomum encontrar o idoso com a prescrição de 80 cápsulas por dia.” (LENHARO, 2012).

No Brasil, embora o grupo de centenários triplicarem em uma década: "Os que chegam melhor ao centenário, segundo pesquisadores, são os de classes mais altas, com maior acesso aos serviços de educação e saúde.” (MILHORANCE, 2015).

No que tange a sustentabilidade, esse novo quadro social de expectativa de vida aumentada, com o avanço da medicina e atividades laborais, possibilitou ao idoso demonstrar maior capacidade, vigor físico, e, sobretudo, um ser ativo financeiramente e socialmente. Entretanto, tais qualidades cresceram desproporcionalmente às políticas estratégicas. Consoante Lenharo:

Por essa razão, o relatório sugere a adoção de novas políticas, estratégias, planos e leis específicas para os mais velhos. Hoje, $47 \%$ dos idosos e 23,8\% das idosas participam da força de trabalho. O drama é quando eles deixarem de trabalhar. Apenas um terço dos países do mundo, que somam $28 \%$ da população mundial, conta com planos de proteção social abrangente para os idosos. Nos países em desenvolvimento, os custos com pagamento de pensão para a população idosa variam de $0,7 \%$ a $2,6 \%$ do Produto Interno Bruto (PIB).

[...] No Brasil que tem 23,5 milhões de idosos, de acordo com a Pesquisa Nacional por Amostra de Domicílios (PNAD) de 2011, a questão previdenciária também é apontada como o principal problema decorrente do envelhecimento, segundo o geriatra Fernando Bignardi, coordenador do Centro de Estudos do Envelhecimento da Unifesp. "Todo o processo foi calculado para pessoas que viveriam até 70 anos. 


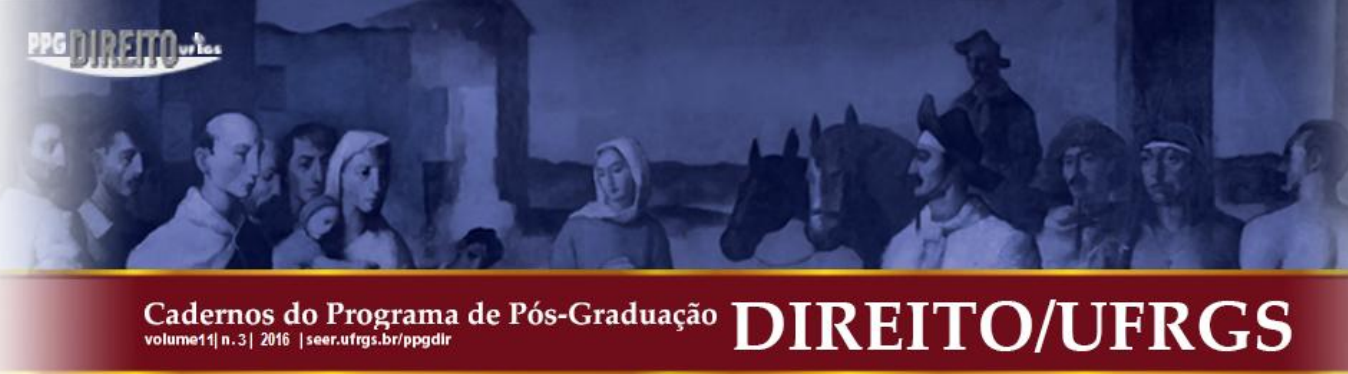
Com o aumento dos anos de vida, está havendo um furo no cálculo. Agora é preciso
pensar em como garantir uma renda mínima para as pessoas que estão
envelhecendo." (LENHARO, 2012).

Enfim, considerando que as taxas de fecundidade e mortalidade ocorreram em ritmos inversos entre diversos países, o desafio será não prolongar a vida, mas sim, estabelecer parâmetros assistenciais para a manutenção de uma qualidade de vida ativa.

\section{A LEGISLAÇÃO AFETA AO DIREITO DO IDOSO}

O envelhecimento é um processo natural que todo ser humano está submetido, sendo necessário ter qualidade de vida nesse processo biológico, físico e emocional. As transformações no decorrer da trajetória de vida de um idoso demarcam obstáculos que antes pareciam corriqueiros, mas, infelizmente passaram a ser difíceis de se transpor. É especialmente nessa fase da vida que se faz necessário o amparo familiar e o respeito das garantias impostas pela legislação.

Diante do descaso sofrido pelo idoso, a vigência de dispositivos no ordenamento jurídico fez-se indispensável, constando na Constituição Federal 1988, no Código Civil Brasileiro - Lei 10.406/2002, e nas leis específicas - Lei n 10.741/2003 (Estatuto do Idoso), Lei ${ }^{\circ}$ 8.842/1994 (Política Nacional do Idoso) e a Lei Orgânica da Assistência Social (Lei no $8.742 / 1993)$.

\subsection{A Constituição da República de 1988 e o Idoso}

A Constituição da República de 1988 obteve um papel de destaque para as transformações do Direito de Família, que deixa de ser um instituto submetido às vontades impostas pelo Estado e por uma tradição patriarcalista, passando os seus componentes a gozarem de suas individualidades e outros direitos essenciais.

Nesse contexto, o idoso recebeu status de cidadão, contemplado pelo princípio da dignidade da pessoa humana, expresso no artigo $1^{\circ}$, inciso III, da CR/88, recebendo amparo específico, nos artigos 229 e 230 da Carta Maior:

Art. 229. Os pais têm o dever de assistir, criar e educar os filhos menores, e os filhos maiores têm o dever de ajudar e amparar os pais na velhice, carência ou enfermidade. 


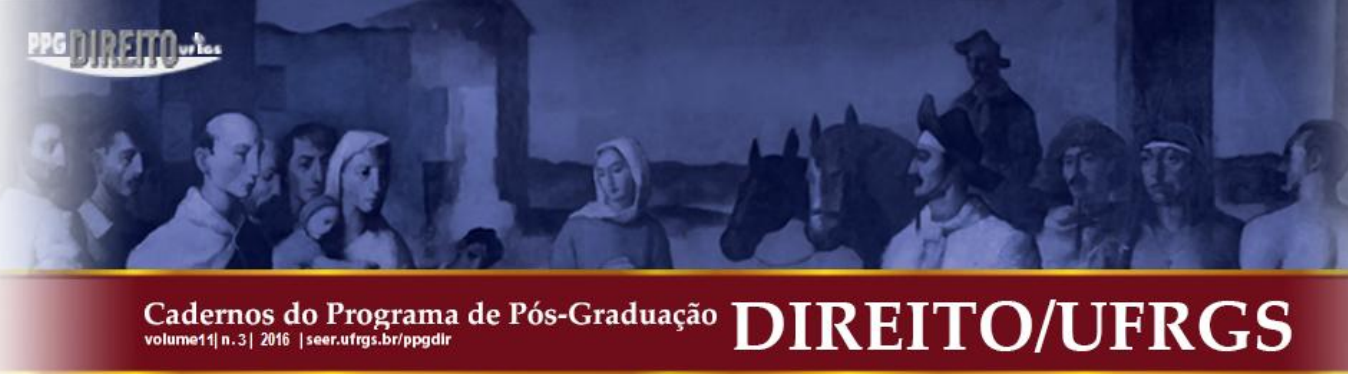

Art. 230. A família, a sociedade e o Estado têm o dever de amparar as pessoas
idosas, assegurando sua participação na comunidade, defendendo sua dignidade e
bem-estar e garantindo-lhes o direito à vida.
$\S 1^{\circ}$ Os programas de amparo aos idosos serão executados preferencialmente em
seus lares.
$\S 2^{\circ}$ Aos maiores de sessenta e cinco anos é garantida a gratuidade dos transportes
coletivos (BRASIL, 1988).

Os mencionados dispositivos são normas de aplicabilidade imediata, calcada nos princípios da solidariedade, afetividade, dignidade da pessoa humana e da proteção integral, o que, em tese, dispensaria outra regulamentação no âmbito jurídico.

Não se trata, portanto, de mera faculdade atentar-se para as necessidades do idoso, mas sim um dever que a família, a sociedade e o Estado estão destinados a cumprir, sob pena de responder civilmente pela omissão.

\subsection{O Código Civil Brasileiro (Lei 10.406, 10 de janeiro de 2002) e o Idoso}

Todo idoso tem direitos personalíssimos, ou seja, possuem a capacidade de decidir sua própria vida, não devendo ser privados dos direitos que, em tese, são intransmissíveis e irrenunciáveis. Nos termos do artigo 11 do CC/2002: “Com exceção dos casos previstos em lei, os direitos da personalidade são intransmissíveis e irrenunciáveis, não podendo o seu exercício sofrer limitação voluntária.” (BRASIL, 2002).

Cabe à família o apoio ao idoso, não devendo jamais expropriar de suas próprias decisões ainda que com o argumento de protegê-lo. Afinal, a idade não está atrelada ao exercício da capacidade, sendo certo que o idoso somente será impedido de gerir a sua própria vida, após comprovada judicialmente a sua incapacidade.

O Código Civil de 2002 se mostra restritivo ao direito de liberdade e a dignidade da pessoa humana, quando reduz a autonomia do idoso, constrangendo-o a uma tutela reducionista, além do caráter discriminatório quando impõe, de forma absurda, aos idosos maiores de 70 anos o regime de separação obrigatória de bens no casamento, em função da idade (art. 1641, CC/02).

A limitação à autonomia da vontade pela idade é inconstitucional, por violação ao direito à igualdade e à liberdade, sendo impossível a discriminação em função do seu sexo ou da sua idade, como causas naturais de incapacidade civil. 


\subsection{O Estatuto do Idoso (Lei $n^{\circ} 10.741,1^{\circ}$ de outubro de 2003)}

A Lei 10.741/03, de $1^{\circ}$ de outubro de 2003, que instituiu o "Estatuto do Idoso", se dividiu em sete títulos, dentre eles o direito à liberdade, respeito, dignidade, saúde, habitação, transporte, proteção, atendimento, acesso à justiça, crimes e alimentação, versando sobre direitos fundamentais e garantias constitucionais aos maiores de 60 anos. Segundo Cielo e Vaz (2009):

Criado com o objetivo de garantir dignidade ao idoso, [...] o Estatuto do Idoso [...] veio em boa hora, com objetivo de dar continuidade ao movimento de universalização da cidadania, levando até o idoso a esperança de que seus anseios e necessidades estão de fato garantidos. (CIELO; VAZ, 2009, p. 42).

O Estatuto do Idoso é marcado por um conjunto de normas possuidoras de um cunho moral que já deveriam estar implícitos na formação educacional de todo e qualquer ser humano. O Estatuto responsabiliza a família, o Estado e a sociedade.

Consoante o artigo $9^{\circ}$ do Estatuto do Idoso "É obrigação do Estado garantir à pessoa idosa a proteção à vida e à saúde, mediante efetivação de políticas sociais públicas que permitam um envelhecimento saudável e em condições de dignidade”.

O Estatuto do Idoso veio garantir não somente o direito a saúde como forma de efetivar a qualidade de vida do idoso, mas também demonstrar que a medicina não seria a única forma de prover uma qualidade de vida, atrelada principalmente ao convívio familiar. Todavia, ao mesmo tempo em que os direitos dos idosos foram formalizados, o Estado mostrou-se inerte quanto à sua atuação para amenizar as transformações que foram sendo conquistadas nessa trajetória incessante.

Atualmente, colhem-se os frutos desse planejamento que, infelizmente, não será pautado somente em pontos positivos, afinal, ainda existe o preconceito de incapacidade interligado à idade.

Como pontos positivos da regulamentação do idoso, têm-se o atendimento preferencial no Sistema Único de Saúde; o recebimento de medicamentos e aparelhos de reabilitação/tratamento pelo Estado; a proibição dos planos de saúde de reajustar as mensalidades, conforme a idade do paciente; transportes coletivos, em que os maiores de 65 anos têm gratuidade, com a reserva de $10 \%$ dos assentos para idosos; o reconhecimento de pessoa ativa e merecedora da participação em sociedade, proteção contra a violência e abandono, estando sujeito às sanções quem adotar conduta ativa ou omissiva; o atendimento 


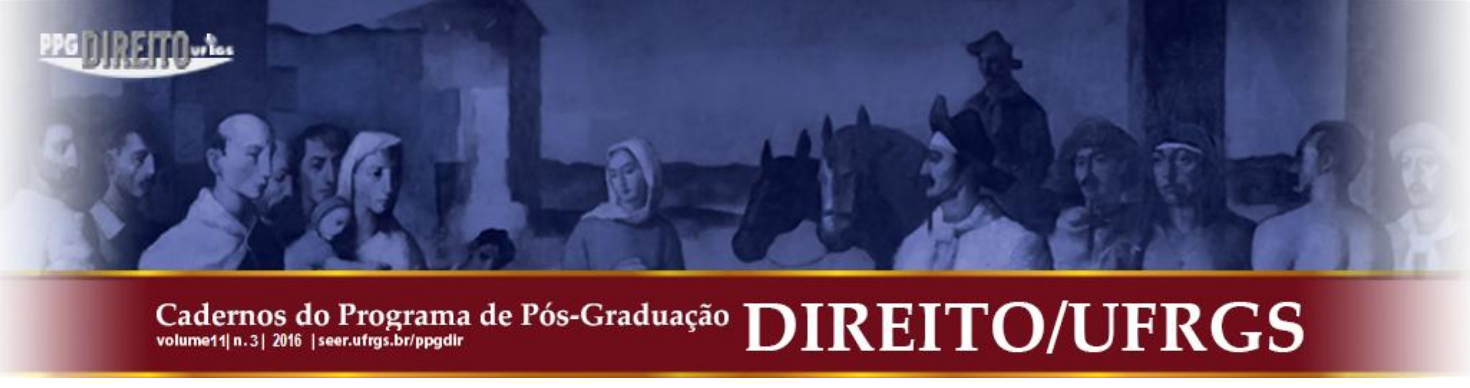

preferencial e imediato em todos os órgãos públicos e privados; as vagas preferências em estacionamento; sistema de cotas nas moradias construídas com recursos federais (percentual de $3 \%$ ) e salário mínimo mensal a todos os idosos com mais de sessenta e cinco anos, o que representou uma redução de dois anos a menos que a Lei Orgânica da Assistência Social.

Dentre os pontos negativos estão à falta de programas educacionais específicos aos idosos; a insuficiência de cursos de alfabetização específicos; não indicação de atividades que façam despertar a vontade de viver e a qualidade de vida dos idosos; o sistema previdenciário é falho, considerado pelos idosos como um verdadeiro lamurio, afinal, não se aplica a política de reajuste que garanta a manutenção de valor dos salários iniciais.

\subsection{A Lei Orgânica da Assistência Social (Lei no 8.742, 07 de dezembro de 1993)}

A assistência social brasileira está positivada nos artigos 6º 194 e 203 da Constituição da República de 1988. Cuida-se de direito social que exige do Estado Brasileiro a atuação no sentido de reduzir desigualdades e garantir o mínimo social aos indivíduos em situação de vulnerabilidade e risco social. Em outras palavras, trata-se de direito fundamental de prestação material, direito público subjetivo dos necessitados e obrigação jurídica dos Poderes Públicos.

A velhice, como fase da vida em que naturalmente há maior vulnerabilidade do indivíduo, reclama especial atenção do Estado, exigindo políticas públicas que procurem conciliar a assistência devida aos idosos.

Pautado nesse entendimento e a fim de assegurar a Seguridade Social, a Lei Orgânica da Assistência Social deixou de ser vista como uma mera política isolada e complementar a Previdência, ganhando reforço no seguinte dispositivo de nossa Carta Maior: “Art. 194. A seguridade social compreende um conjunto integrado de ações de iniciativa dos Poderes Públicos e da sociedade, destinadas a assegurar os direitos relativos à saúde, à previdência e à assistência social.” (BRASIL, 1988).

A concessão do benefício assistencial amparado pela Lei Orgânica da Assistência Social (LOAS) tem como fonte principal o inciso V, do artigo 203 da Constituição Federal de 1988, in verbis:

Art. 203. A assistência social será prestada a quem dela necessitar, independentemente de contribuição à seguridade social, e tem por objetivos: 


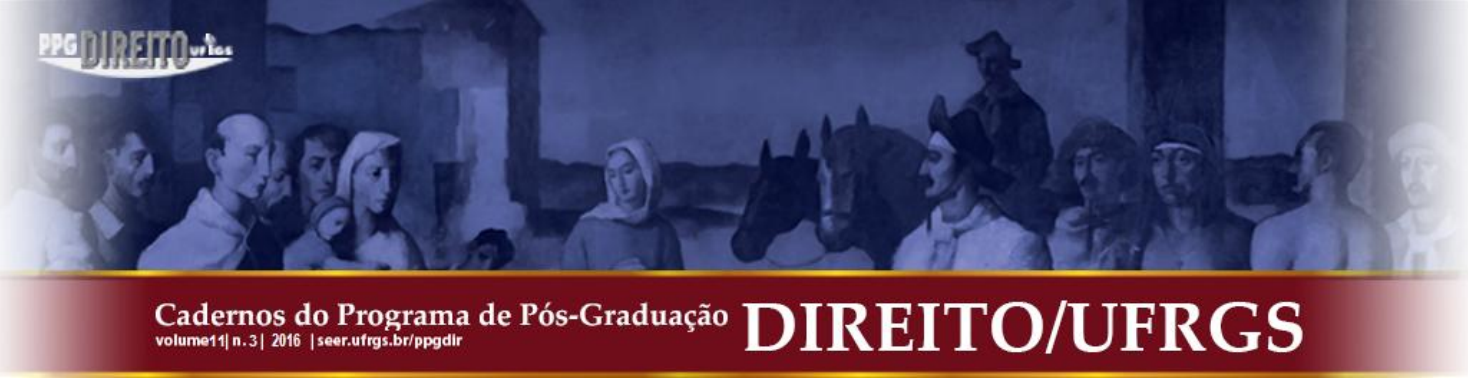

$[\ldots]$

V - a garantia de um salário mínimo de benefício mensal à pessoa portadora de deficiência e ao idoso que comprovem não possuir meios de prover à própria manutenção ou de tê-la provida por sua família, conforme dispuser a lei. (BRASIL, 1988).

Por se referir a um benefício assistencial, o indivíduo não precisa ter contribuído para os quadros orçamentários da Previdência Social, todavia, há requisitos para se ter acesso a tal amparo assistencial (gênero da seguridade social, intransferível, não acumulado com qualquer outro beneficio da de regime previdenciário), são eles: IDADE: Possuir 65 (sessenta e cinco) anos de idade.

Art. 34 do Estatuto do Idoso: Aos idosos, a partir de 65 (sessenta e cinco) anos, que
não possuam meios para prover sua subsistência, nem de tê-la provida por sua
família, é assegurado o benefício mensal de 1 (um) salário-mínimo, nos termos da
Lei Orgânica da Assistência Social - Loas.
Parágrafo único. O benefício já concedido a qualquer membro da família nos termos
do caput não será computado para os fins do cálculo da renda familiar per capita a
que se refere a Loas. (Vide Decreto $\mathrm{n}^{\circ}$ 6.214, de 2007).

Há também a possibilidade de idosos estrangeiros naturalizados e domiciliados legalmente no Brasil obterem direito a esse benefício, pois a Constituição Federal de 1988 consagra a ideia de que assistência social será prestada a quem dela necessitar, independente de contribuição social. Nesse contexto, existe a necessidade de fiscalização mais abrangente por parte do Brasil, afinal não é afastável a ideia de imigrantes se estabelecerem temporariamente em nosso território a fim de somente adquirir o benefício.

\footnotetext{
BENEFÍCIO ASSISTENCIAL. CONCESSÃO A ESTRANGEIRO LEGALMENTE RESIDENTE NO PAÍS. POSSIBILIDADE. A condição de estrangeiro legalmente residente no Brasil não impede a concessão de benefício assistencial ao idoso ou deficiente, pois a Constituição Federal, art. $5^{\circ}$, assegura ao estrangeiro residente no país o gozo dos direitos e garantias individuais em igualdade de condição com o nacional. A concessão do amparo, porém, deve ser afastada se restar demonstrado que o estrangeiro transferiu residência para o Brasil apenas com intuito de auferir o benefício em exame. Incidente conhecido e improvido. (TRU4, IUJEF 2007.70.95.014089-0, Rel. Juiz Federal Rony Ferreira, D.E. 17.09.2008). (PORTO ALEGRE, 2008).
}

Outro requisito é a RENDA, ou seja, para se ter acesso ao benefício assistencial, o idoso não pode ter meios de prover a sua própria subsistência, tampouco ser assistido economicamente por sua família (aquela em que a renda mensal familiar per capita seja inferior a $1 \frac{1}{4}$ do salário mínimo). 


\subsection{A Política Nacional do Idoso (Lei no 8.842, 04 de janeiro de 1994)}

A Política Nacional do Idoso, estabelecida pela Lei n ${ }^{\circ}$ 8.842, de 04 de janeiro de 1994, foi vista como uma estratégia jurídico-legal no tocante a implementação de diretrizes políticas aos municípios brasileiros, para a conquista e a defesa da população idosa, que cresce cada vez mais. Foram criadas, portanto, normas para o exercício dos direitos dos nossos queridos idosos, de forma que garantissem a participação efetiva, autonomia e a integração, como é estabelecido em seu art. $4^{\circ}$.

\footnotetext{
Art. $4^{\circ}$ Constituem diretrizes da política nacional do idoso:

I - viabilização de formas alternativas de participação, ocupação e convívio do idoso, que proporcionem sua integração às demais gerações;

II - participação do idoso, através de suas organizações representativas, na formulação, implementação e avaliação das políticas, planos, programas e projetos a serem desenvolvidos;

III - priorização do atendimento ao idoso através de suas próprias famílias, em detrimento do atendimento asilar, à exceção dos idosos que não possuam condições que garantam sua própria sobrevivência;

IV - descentralização político-administrativa;

$\mathrm{V}$ - capacitação e reciclagem dos recursos humanos nas áreas de geriatria e gerontologia e na prestação de serviços;

VI - implementação de sistema de informações que permita a divulgação da política, dos serviços oferecidos, dos planos, programas e projetos em cada nível de governo; VII - estabelecimento de mecanismos que favoreçam a divulgação de informações de caráter educativo sobre os aspectos biopsicossociais do envelhecimento;

VIII - priorização do atendimento ao idoso em órgãos públicos e privados prestadores de serviços, quando desabrigados e sem família;

IX - apoio a estudos e pesquisas sobre as questões relativas ao envelhecimento.

Parágrafo único. É vedada a permanência de portadores de doenças que necessitem de assistência médica ou de enfermagem permanente em instituições asilares de caráter social. (BRASIL, 1994).
}

A partir do advento da Lei $n^{\circ}$ 8.842/1994, em 1997, foi editado o Plano de Ação Governamental para Integração da Política Nacional do Idoso. São nove os órgãos que compõem este Plano: Ministérios da Previdência e Assistência Social, da Educação, da Justiça, Cultura, do Trabalho e Emprego, da Saúde, do Esporte e Turismo, Transporte, Planejamento e Orçamento e Gestão.

Não obstante a lei seja enfática, não está sendo eficientemente aplicada, pois, de um lado, tem-se uma sociedade desinteressada e, de outro, um Estado despreparado para a articulação de objetivos em comum de um mesmo grupo, por meio de órgãos da saúde, educação e assistência social. 


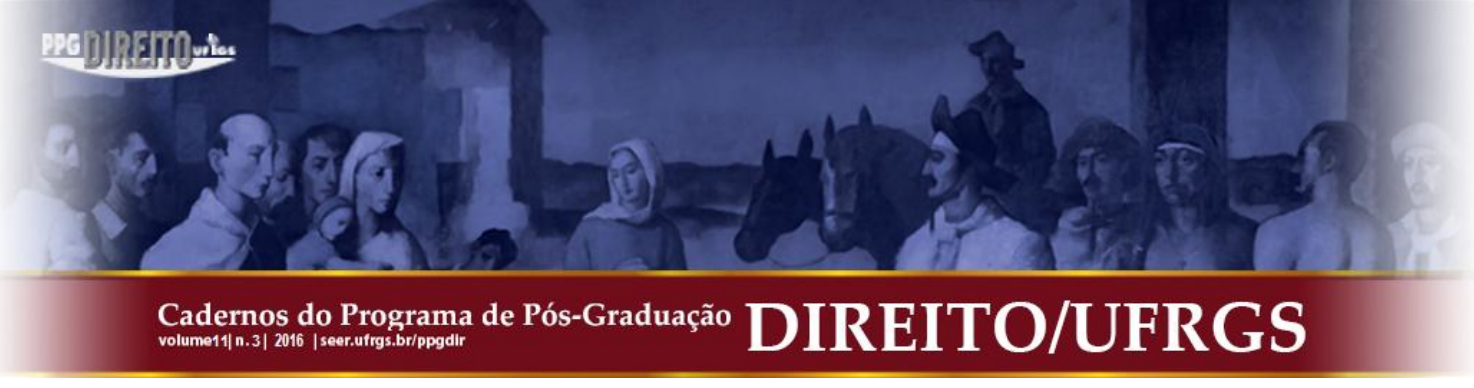

A garantia de acesso dos idosos aos direitos que lhes são assegurados de forma expressa pela lei são nada mais nada menos que o reconhecimento de sua cidadania, e, como consequência, seus direitos e deveres devem ser oportunizados tanto na esfera governamental, quanto na sociedade civil, afinal, a capacidade não é condicionada indispensavelmente em função da idade.

\section{AS OBRIGAÇÕES DOS FILHOS EM FACE DOS PAIS IDOSOS}

Conforme já destacado, o dever dos filhos em relação aos pais idosos não veio delimitado apenas no Estatuto do Idoso (Lei $\mathrm{n}^{\mathrm{o}} 10.741,1^{\circ}$ de outubro de 2003), sendo respaldado pelo art. 229 da CR/88: "os pais têm o dever de assistir, criar e educar os filhos menores, e os filhos maiores têm o dever de ajudar e amparar os pais na velhice, carência ou enfermidade". (BRASIL, 1988).

Paralelo a esse dispositivo, o Estatuto do Idoso reforça a obrigação de cuidado, em seu $\operatorname{artigo} 3^{\circ}$ :

Art. $3^{\circ}$. É obrigação da família, da comunidade, da sociedade e do Poder Público assegurar ao idoso, com absoluta prioridade, a efetivação do direito à vida, à saúde, à alimentação, à educação, à cultura, ao esporte, ao lazer, ao trabalho, à cidadania, à liberdade, à dignidade, ao respeito e à convivência familiar e comunitária. (BRASIL, 2003).

A Constituição Federal de 1988 atribui primeiramente à família o dever de cuidado aos pais idosos podendo se extrair que esse cuidado deve advir primeiramente de seus descendentes. Nessa seara, não se pode esquecer que embora exista uma "ordem de preferência", muitos filhos não estão preparados para receber seus pais idosos.

Enfim, a obrigação dos filhos em relação aos pais idosos consubstancia-se num dever legal a ser cumprido, devendo ser analisado, concomitante, à necessidade de existir o afeto quem vem implícito, por exemplo, quando a demonstração de um simples ato de carinho de um filho pode ser a salvação da vida de um pai.

\subsection{O Abandono}

Antes de se adentrar ao abandono dos idosos é necessário, primeiramente, ter conhecimento do que poderia ser o abandono. 


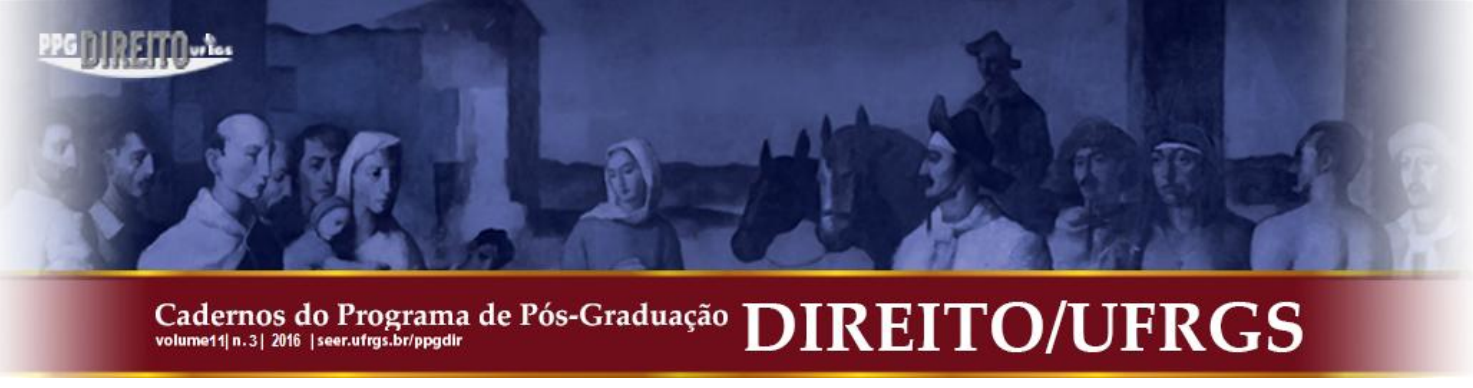

No campo jurídico, o abandono se dá quando alguém se abstém de forma negligencial em relação a uma pessoa ou a um bem em determinada situação, causando consequiências jurídicas.

O abandono será material, quando o idoso é privado de acesso a itens básicos de sua subsistência, seja água, comida e roupagem adequada, contrariando dispositivos legais e comprometendo a expectativa de vida digna do idoso. Nesse sentido, o idoso encontra-se respaldado nos já mencionados arts. 229 da CR/88, 1.696 do CC/02, bem como no art. 244 do Código Penal, in verbis:

Art. 244 - Deixar, sem justa causa, de prover a subsistência do cônjuge, ou de filho menor de 18 (dezoito) anos ou inapto para o trabalho, ou de ascendente inválido ou maior de 60 (sessenta) anos, não lhes proporcionando os recursos necessários ou faltando ao pagamento de pensão alimentícia judicialmente acordada, fixada ou majorada deixar, sem justa causa, de socorrer descendente ou ascendente, gravemente enfermo: (Alterado pela L-010.741-2003) Pena - detenção, de 1 (um) a 4 (quatro) anos e multa, de uma a dez vezes o maior salário mínimo vigente no País (BRASIL, 1941).

O Estatuto do Idoso dispõe:

Art. $3^{\circ}$ : É obrigação da família, da comunidade, da sociedade e do Poder Público assegurar ao idoso, com absoluta prioridade, a efetivação do direito à vida, à saúde, à alimentação, à educação, à cultura, ao esporte, ao lazer, ao trabalho, à cidadania, à liberdade, à dignidade, ao respeito e à convivência familiar e comunitária.

[...]

Art. 99. Expor a perigo a integridade e a saúde, física ou psíquica, do idoso, submetendo-o a condições desumanas ou degradantes ou privando-o de alimentos e cuidados indispensáveis, quando obrigado a fazê-lo, ou sujeitando-o a trabalho excessivo ou inadequado:

Pena - detenção de 2 (dois) meses a 1 (um) ano e multa.

$\S 1^{\circ}$ Se do fato resulta lesão corporal de natureza grave:

Pena - reclusão de 1 (um) a 4 (quatro) anos.

$\S 2^{\underline{0}}$ Se resulta a morte:

Pena - reclusão de 4 (quatro) a 12 (doze) anos. (BRASIL, 2003).

O abandono material, considerado um crime de desamor, caracteriza-se pela omissão injustificada na assistência familiar, ocorrendo quando o responsável pelo sustento de uma determinada pessoa deixa de contribuir com a subsistência material de outra, não lhe proporcionando recursos necessários ou faltando com o pagamento de alimentos fixados judicialmente.

Por outro lado, é amparado juridicamente o dever obrigacional de prestar auxílio imaterial (obrigações jurídicas imateriais), englobando o não cumprimento de deveres filiais pautados na convivência familiar e o amparo ao idoso. O abandono pode ser caracterizado 


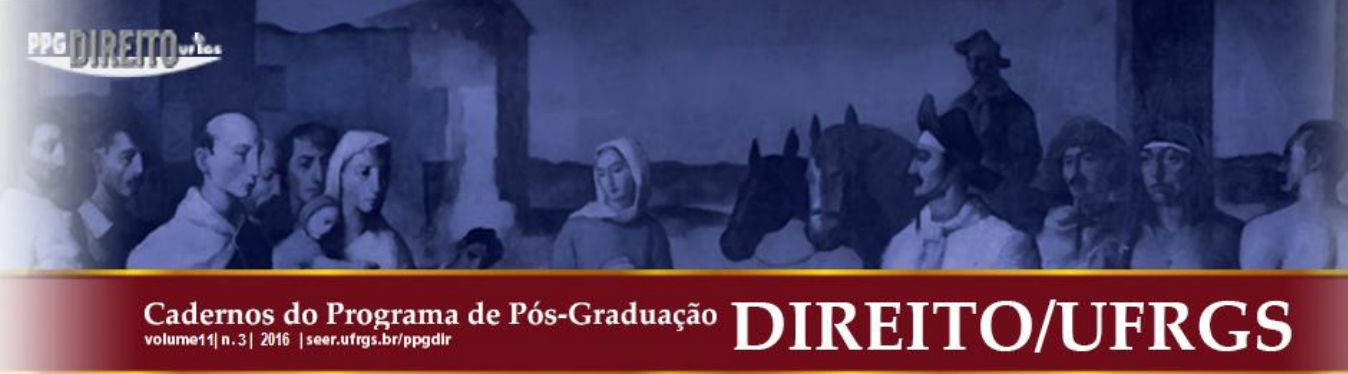

pelo simples fato de se chegar ao imóvel, constatar que o idoso não está sendo medicado adequadamente ou se ele não está tendo a higiene adequada. Isso já é uma questão de abandono. (FILHOS, 2010).

O conviver que é basicamente afetivo, enriquecido com uma convivência mútua, alimenta o corpo, mas também cuidar da alma, da moral, do psíquico. Essas são as prerrogativas do poder familiar. (SILVA, 2000)

O abandono imaterial de idosos é combatido no art. 229 da CR/88, o qual exalta o dever recíproco existente na relação entre pais e filhos, valorizando as relações afetivas, bem como no art. $4^{\circ}$ do Estatuto do Idoso que prevê:

\footnotetext{
Art. $4^{\text {o: }}$ Nenhum idoso será objeto de qualquer tipo de negligência, discriminação, violência, crueldade ou opressão, e todo atentado aos seus direitos, por ação ou omissão, será punido na forma da lei.

$[\ldots]$

Art. 98. Abandonar o idoso em hospitais, casas de saúde, entidades de longa permanência, ou congêneres, ou não prover suas necessidades básicas, quando obrigado por lei ou mandado:

Pena - detenção de 6 (seis) meses a 3 (três) anos e multa.

Art. 99. Expor a perigo a integridade e a saúde, física ou psíquica, do idoso, submetendo-o a condições desumanas ou degradantes ou privando-o de alimentos e cuidados indispensáveis, quando obrigado a fazê-lo, ou sujeitando-o a trabalho excessivo ou inadequado:

Pena - detenção de 2 (dois) meses a 1 (um) ano e multa.

$\S 1^{\circ}$ Se do fato resulta lesão corporal de natureza grave:

Pena - reclusão de 1 (um) a 4 (quatro) anos.

$\S 2^{\mathrm{o}}$ Se resulta a morte:

Pena - reclusão de 4 (quatro) a 12 (doze) anos. (BRASIL, 2003).
}

$\mathrm{O}$ referido Estatuto, em seu artigo $2^{\circ}$, também protege a dignidade dos idosos, coibindo todos os atos que prejudiquem sua saúde mental e física. As obrigações jurídicas imateriais mencionadas são deveres de ordem moral, que quando descumpridas, ocasionam danos emocionais incalculáveis. A rejeição dos familiares, por exemplo, poderá causar danos de ordem moral devastadores, causando doenças que ocasionarão, certamente, a diminuição dos anos de vida e a sensação de perda da dignidade humana, amplamente protegidos no Ordenamento Jurídico.

Assim, quando o filho não ampara seu pai na velhice deixa de cumprir uma obrigação imaterial, cometendo, assim, um ato ilícito, que gera o pagamento de indenização por danos morais. A assistência emocional também é uma obrigação legal dos filhos, sob o aspecto existencial, de acordo com a norma constitucional do art. 229 da CR/88. Esta norma legal engloba, além do sustento, a assistência imaterial concernente ao afeto, ao cuidado e ao amor. 


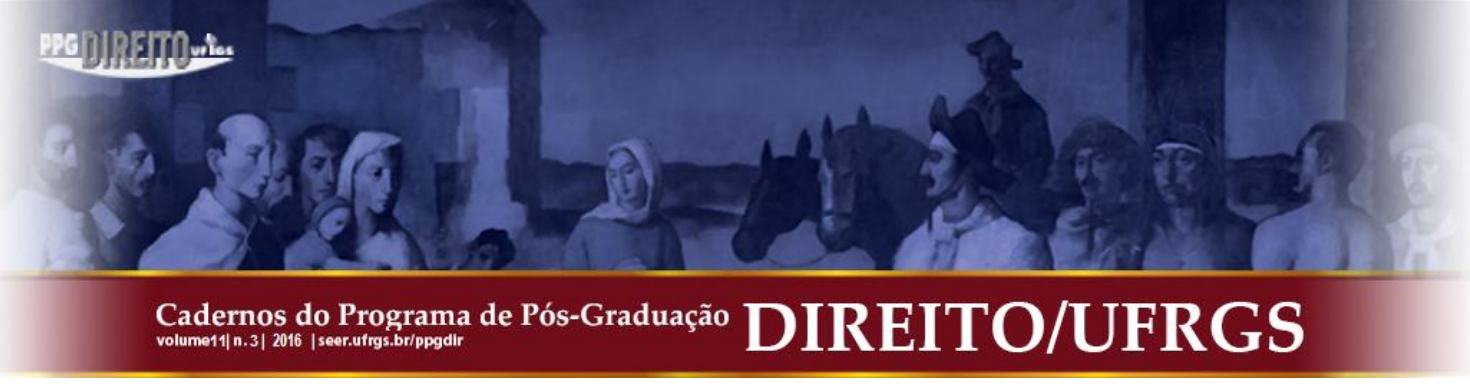

O abandono afetivo, portanto, traduz-se no apoio, no cuidado, na participação na vida do idoso e no respeito por seus direitos da personalidade como o direito de conviver no âmbito da família. Sabe-se que não se pode impor o afeto e tampouco precificá-lo, pelo fato de não existir obrigação legal de amar. Azevedo (2004):

O descaso entre pais e filhos é algo que merece punição, é abandono moral grave, que precisa merecer severa atuação do Poder Judiciário, para que se preserve não o amor ou a obrigação de amar, o que seria impossível, mas a responsabilidade ante o descumprimento do dever de cuidar, que causa o trauma moral da rejeição e da indiferença. (AZEVEDO; 2004, p. 14).

Vê-se, pois, a existência de abandono material, imaterial ou afetivo do idoso.

\subsection{O Afeto}

Em termos sociológicos, o afeto apresenta um papel crucial para o aprendizado do ser humano, possibilitando que sentimentos sejam revelados, que laços de amizades e familiares sejam reforçados.

Pode-se considerar a existência de duas espécies de afeto, o objetivo e o subjetivo. No afeto objetivo, as obrigações de cuidado são metas jurídicas a serem alcançadas, respaldadas pelas normas jurídicas afetas ao idoso. Por outro lado, o afeto subjetivo relaciona-se com as emoções, sentimentos exteriorizados ou por vezes reprimidos.

No âmbito jurídico, o tema afeto tornou-se bastante recorrente e polêmico, sendo necessário analisar o caso concreto de forma prudente e cautelosa. Embora o Princípio da Afetividade não esteja expresso em nosso ordenamento jurídico, encontra-se implícito em inúmeras disposições positivadas em nossa Constituição Federal: na igualdade de filhos, independente de origem (artigo $227 \S 6^{\circ}$ ), na adoção; no reconhecimento da união estável (artigo $226 \$ 3^{\circ}$ ), na família homoafetiva (artigo $2^{\circ}$ da lei 11340/2006), na liberdade de decisão sobre o planejamento familiar (artigo $226 \S 7^{\circ}$ ), dentre outros.

Para Paulo Roberto Iotti Vecchiatti (2008):

[...] o elemento formador da família contemporânea, visto que se não é alguma formalidade que gera a entidade familiar juridicamente protegida, então só pode ser o sentimento de amor, aliada a comunhão plena de vida e interesses, de forma pública, contínua e duradoura, o que forma a entidade familiar protegida pela Constituição Federal. (VECCHIATTI, 2008, p. 215). 


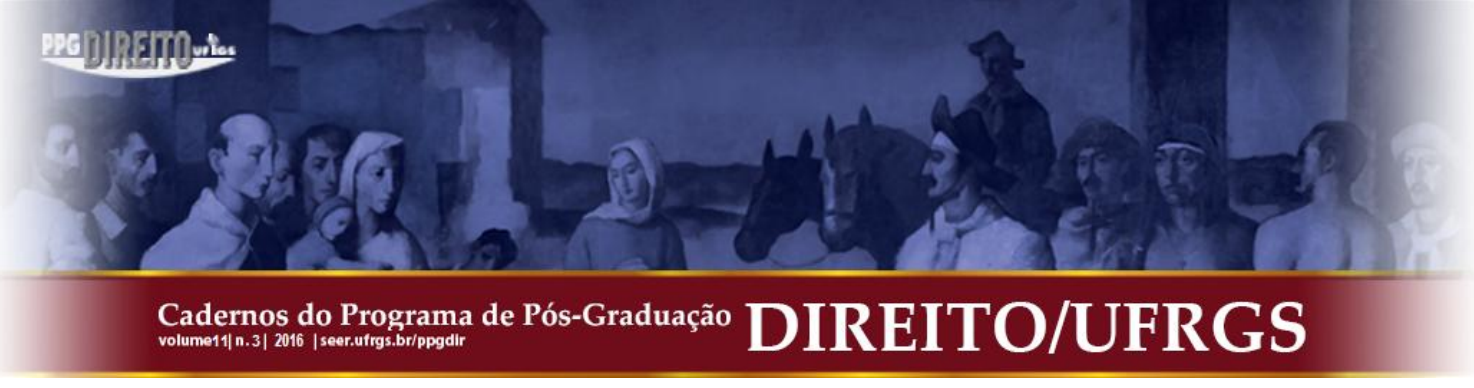

Dessa maneira, o afeto deixou de ser algo presumido em núcleos familiares e passou a ser norteador para a formação de uma estrutura familiar sólida, merecedor de abrigo no Direito de Família, pautado no respeito, e, principalmente, no amor.

Após essa breve consideração sobre o afeto, faz-se necessário analisar a sua aplicação no Direito do Idoso. O envelhecimento não pode ser atrelado somente a "perdas", entretanto, não se pode "fechar os olhos" para a perda da posição social comum após a aposentadoria, a pobreza que dificulta as condições mínimas de sobrevivência e a solidão. Além disso, verificam-se, muitas vezes, que os idosos têm pouco contato com outras pessoas devido à dificuldade de transporte adequado, problemas financeiros, incapacidade física e falta de companhia associada à perda de amigos e ao descaso de familiares.

O reconhecimento jurídico do afeto na vida dos idosos não se trata de se impor o amor, afinal, é impossível fazer brotar algo que nasce naturalmente em qualquer ser humano. A questão aqui está voltada é para um dever de cuidado de pais para filhos e destes com os pais.

Os recursos materiais, obviamente, são indispensáveis para a sobrevivência do idoso, todavia, não somente eles, o afeto ou a falta dele, sem sombra de duvidas, causa efeitos, pois o idoso que vive num meio afetivo e fraterno possui mais força para vencer os infortúnios da vida. É necessário ter consciência de que os medos e as inseguranças não estão atrelados somente aqueles que estão vivenciando a infância, na velhice, estes apenas se manifestam de forma diferente.

O envelhecimento, embora muitas vezes seja traga consigo um processo de perda física, necessariamente, vem acompanhado de acúmulo de experiência emocional e de vida, sobretudo, para aqueles que se disponibilizam a vivenciar o real sentido da palavra afeto.

Por fim, impossível deixar de fazer uma pequena ressalva, no tocante a leveza e relevância da atuação do cuidador na vida dos nossos queridos idosos, ou seja, o afeto não é algo restringido apenas por laços sanguíneos, o que é entristecedor é ter que reforçar uma obrigação respaldada e inerente aos próprios filhos. 


\section{RESPONSABILIDADE CIVIL: BREVES CONSIDERAÇÕES}

Savatier (2005, p. 40) define o conceito de responsabilidade civil com clareza e precisão, nos seguintes termos: "é a obrigação de alguém reparar dano causado a outrem por fato seu, ou pelo fato das pessoas ou coisas que dele dependam".

A Constituição Federal de 1988, ao consagrar o princípio da Dignidade da Pessoa Humana como basilar da República Federativa, no art. $1^{\circ}$, inciso II, reforçou a transladação do foco do culpado para a vítima, sendo certo que, atualmente, se pode atribuir um paradigma solidarista à responsabilidade civil, que tem como escopo não a punição de quem causou o dano, mas a reparação à vítima, na tentativa de retornar-se ao statu quo ante.

A responsabilidade Civil, portanto, passa a incidir quando aquele que violar um dever jurídico, por meio de ato lícito ou ilícito, tem a obrigação de reparar os danos injustos com o objetivo de reestruturar o equilíbrio violado, no caso do idoso, o dever de cuidado tem sido, recorrentemente, violado.

O Código Civil de 2002 consagrou a responsabilidade subjetiva como regra geral, ou seja, será aplicada sempre que não houver disposição legal expressa impondo a aplicação da teoria objetiva. Os artigos 186 e 927 do Código Civil de 2002 aduziram a cláusula geral da responsabilidade com culpa, a responsabilidade subjetiva.

Todavia, existem pressupostos para serem preenchidos para que surja o dever de indenizar de forma subjetiva: $\mathrm{I}$ - $\mathrm{O}$ ato ilícito e o abuso do direito, fundamentados no artigo 186 e 187 do Código Civil de 2002, respectivamente; II - O dano, quando há lesão a um bem juridicamente protegido pelo ordenamento jurídico, incidindo na esfera patrimonial ou extrapatrimonial, inexistindo a possibilidade de forma tentada. III - O nexo de causalidade também é um importante pressuposto da responsabilidade civil, pois, para a configuração do dever de indenizar não bastam o dano e uma conduta, é preciso que esta conduta tenha dado causa ao dano. IV - A culpa, por fim, refere-se à demonstração de que o autor da conduta não pretendeu o resultado, mas agiu com negligência, imprudência e imperícia. Nas palavras de Amorim (2011):

No primeiro, o agente se porta deixando de agir ou deixa de fazer algo que deveria; No segundo aspecto, o agente age, mas de uma forma imoderada, sem tomar os cuidados necessários para que não houvesse o dano; E por fim, no terceiro aspecto, há uma falta de habilidade técnica para que o agente pudesse agir de forma satisfatória e sem provocar o dano. (AMORIM, 2011, p. 03). 
Certo é que o primeiro pressuposto de qualquer responsabilidade civil seria a conduta, o ato humano, comissivo ou omissivo, que para o direito adquire relevância quando dela surtirem efeitos jurídicos.

O dano, por sua vez, cuida-se do prejuízo moral ou material causado à vítima em razão da conduta comissiva ou omissiva praticada pelo ofensor. Os conceitos doutrinários de dano giram em torno do mesmo ponto: a perda ou a lesão a um bem jurídico. Neste sentido, tem-se o conceito elaborado por Sergio Cavalieri Filho (2010, p. 71):

Conceitua-se, então, o dano como sendo a subtração ou diminuição de um bem jurídico, qualquer que seja sua natureza, quer se trate de um bem patrimonial, quer se trate de um bem integrante da própria personalidade da vítima, como a sua honra, a imagem, a liberdade etc.

O dano é, portanto, o elemento predeterminante da obrigação de indenizar, pois não há indenização sem dano. Cavalieri Filho afirma que "pode haver responsabilidade sem culpa, mas não pode haver responsabilidade sem dano" (2010, p. 70), referindo-se à responsabilidade objetiva, a qual a culpa do agente se encontra presumida na conduta.

O dano pode ser moral ou patrimonial. Este se configura na diminuição econômica do patrimônio da vítima, algo que se pode mensurar pecuniariamente pela análise do patrimônio do lesado após a ocorrência do fato danoso. O dano patrimonial se subdivide em dano emergente, ou seja, os prejuízos reais sofridos pela vítima, a diminuição patrimonial, e, lucros cessantes ou frustrados, aquilo que a vítima deixou de auferir, ambos com fulcro no artigo 402 do CC.

O dano moral, a seu turno, envolve os direitos da personalidade, assim entendidos como os direitos essenciais da pessoa. Nestes casos, não há diminuição econômica do patrimônio da vítima diretamente, mas sim, violação a um bem personalíssimo, que até pode vir a trazer diminuição econômica do patrimônio da vítima.

No particular, a autonomia da pessoa idosa exige a assistência filial, moral e afetiva, obrigação dos filhos de cuidado, imprescindível para a consolidação dos direitos da personalidade existenciais na velhice. Seguindo essa perspectiva, a Lei Maior consagrou em seu art. $5^{\circ}$, incisos $\mathrm{V}$ e $\mathrm{X}$, a proteção aos direitos de personalidade, tidos por invioláveis, prevendo expressamente a possibilidade de indenização pelo dano moral decorrente de sua violação: 


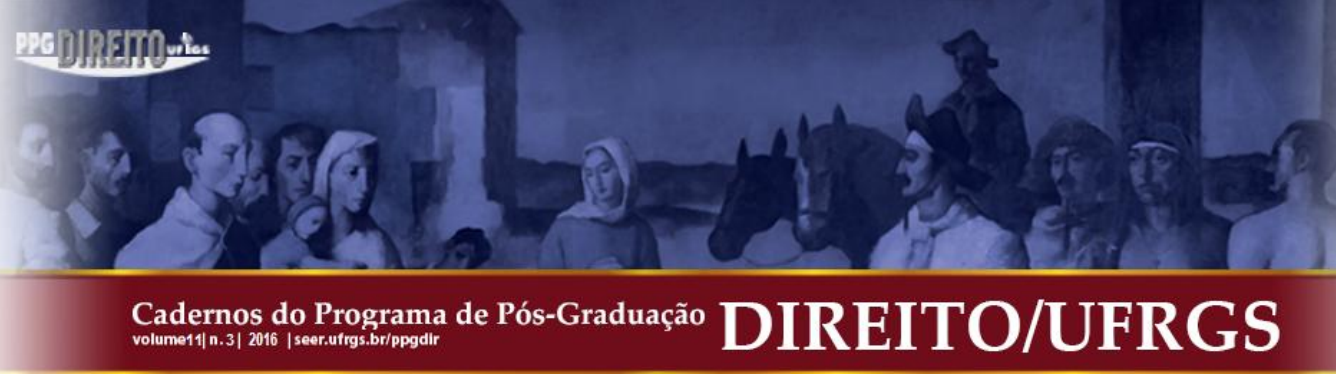
do direito à vida, à liberdade, à igualdade, à segurança e à propriedade, nos termos seguintes:
$[\ldots]$
V - é assegurado o direito de resposta, proporcional ao agravo, além da indenização por dano material, moral ou à imagem;
$[\ldots]$
X - são invioláveis a intimidade, a vida privada, a honra e a imagem das pessoas, assegurado o direito a indenização pelo dano material ou moral decorrente de sua violação; (BRASIL, 1988).

Tal disposição constitucional é regulamentada pelo Código Civil de 2002 em seus artigos 186 e 927 , in verbis:

Art. 186. Aquele que, por ação ou omissão voluntária, negligência ou imprudência, violar direito e causar dano a outrem, ainda que exclusivamente moral, comete ato ilícito.

[...]

Art. 927. Aquele que, por ato ilícito (arts. 186 e 187), causar dano a outrem, fica obrigado a repará-lo. (BRASIL, 2002).

A legislação brasileira, portanto, possibilita a reparação civil, em face do descumprimento do dever de cuidado filial-paterno, sendo o instituto da responsabilidade civil o instrumento para fazer valer os direitos dos idosos, ainda que sob a forma de indenização.

\section{O DANO MORAL NO CONTEXTO DO ABANDONO AFETIVO INVERSO}

O abandono afetivo inverso é constituído, em regra, pela inação de afeto ou, especificamente, pela ausência de cuidado dos filhos em face de seus genitores idosos, fundado no valor jurídico imaterial da solidariedade familiar e da segurança afetiva da família. Apresenta-se no universo jurídico não apenas como uma omissão do dever de cuidado dos filhos em relação aos seus pais idosos, mas sim, como forma de garantir o princípio da dignidade humana, evitando ou compensando o abalo psicológico, físico e social sofrido pelos idosos.

O Abandono Afetivo Inverso se refere a uma "novidade" no campo jurídico, mas com um decorrer histórico antigo. É um tema pouco debatido, infelizmente existe uma vasta literatura jurídica quando se refere ao abandono afetivo de pais com relação aos filhos e o caminho invertido quase nunca é levado em consideração.

A palavra "inverso" inserida no contexto do abandono se relaciona com a equação às avessas do binômio da relação paterno-filial, ou seja, os filhos devem cuidar dos pais idosos, assim como, os pais devem cuidar dos filhos na infância. 


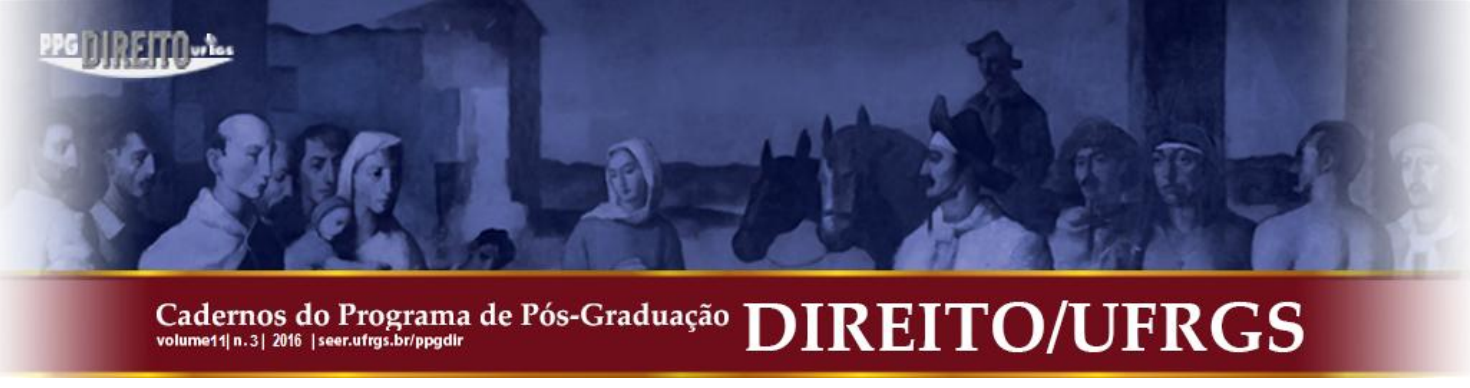

Diante desse contexto, a indagação que se pretende enfrentar seria: é possível haver dever de indenizar por danos morais, no contexto do Abando Afetivo Inverso?

Entende-se, em primeira análise, que sim, como consequência da omissão do dever de cuidado, que se transforma em dor, angústia, sofrimento e, inclusive, no agravamento de doenças para esses idosos abandonados que, de forma alguma, poderão ser compensados.

O fato de não existir legislação específica acerca do não afeto dos filhos perante os seus pais idosos, não significa que estão eximidos de exercerem o dever de cuidado derivado da paternidade responsável, extraídos do preceito constitucional do artigo 229 da Constituição Federal de 1988, segundo o qual "[...] os filhos maiores tem o dever de ajudar e amparar os pais na velhice, carência e enfermidade" (BRASIL, 1988).

Nesse contexto, a convivência familiar é de total importância e isso é facilmente notado quando o idoso se vê abandonado pela própria família, o que ele pode esperar do seu futuro? Quando se diz futuro, certamente, haverá aqueles que indagarão, que futuro? É agora, a obrigação de cuidado não pode ser postergada, pode não haver tempo para esse descuido.

Em acesso a entrevista realizada com Dona Laurinda, 80 anos, que vive no Abrigo São Vicente de Paulo, vê-se, claramente, a necessidade de se reforçar o papel da família:

Eu não lembro quem me trouxe para cá, mas queria morar com meus filhos só que eles não me querem. Eu morava com o caçula, mas depois que ele casou a mulher dele e nem ele me querem mais. Ele diz que eu sou doente e ele não tem tempo de zelar de mim, foi isso que ele falou". Minha filha eu não sei. Meus filhos não me querem, um vive bebendo, outro casou e outro também não me quer. Tenho um neto que é o único que me visita. Eu sinto tanta falta dos meus filhos, às vezes quando eu acordo parece que eu to vendo eles. Tem vezes que eu choro, faz falta demais deles comigo. Eles nem ligam mais, só o mais novo que vem aqui. Eu não tenho nenhuma foto deles. (ALMEIDA, 2005, p. 85).

Não obstante a inexistência de lei específica, o abandono afetivo inverso, como corolário do desprezo, do desrespeito ou da indiferença filial, representa fenômeno jurídico e social de relevância que merece ser discutido pelos operadores de direito.

Entende-se que o instituto Abandono Afetivo Inverso não veio para impor o afeto, mas sim para lembrar aos filhos que, aceitando ou não esta qualidade, jamais estarão "livre" do dever de cuidado para com seus genitores, dever este que, tragicamente e vergonhosamente, necessitou de ser expresso em dispositivo constitucional, para que os filhos pudessem dar valor a quem lhes deu a própria vida. 


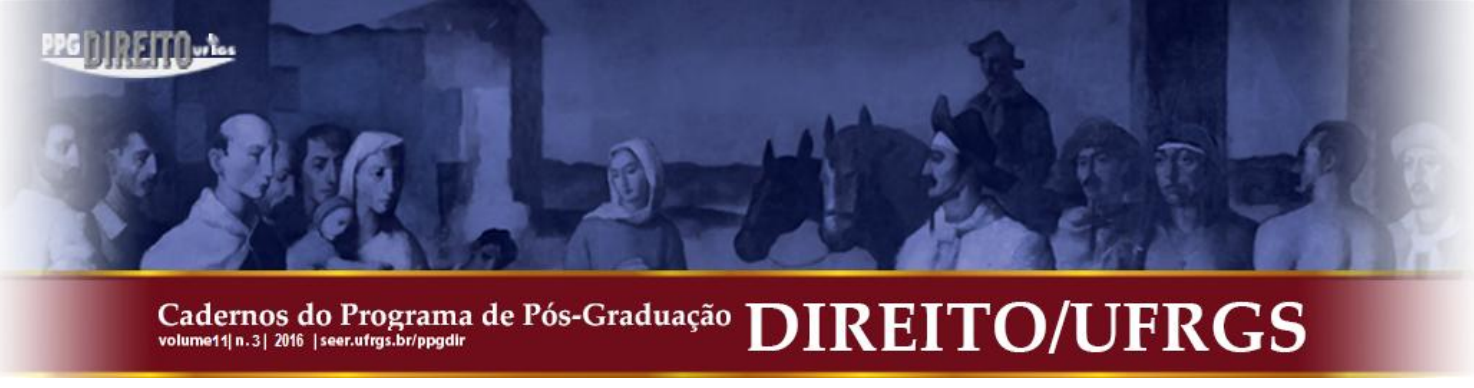

Segundo o desembargador Jones Figueirêdo Alves (PE), diretor nacional do Instituto Brasileiro de Direito de Família (IBDFAM):

\begin{abstract}
A inação de afeto ou, mais precisamente, a não permanência do cuidar, dos filhos para com os genitores, de regra idosos. Segundo o diretor, esta falta do cuidar serve de premissa de base para a indenização. O amor é uma celebração permanente de vida, reflete o desembargador, e, como tal, realidade espontânea e vivenciada do espírito; todavia o abandono moral e material, como instrumento de desconstrução de vida pode ser mensurado em níveis de quantificação indenizatória. Os parâmetros são os circunstanciais de vida dos próprios atores envolvidos, sinalizando uma reparação civil adequada e necessária, complementa. (ABANDONO, 2013).
\end{abstract}

O dano moral, portanto, seria uma forma de tutelar o dever de cuidado que foi violado, concomitantemente, uma ação preventiva com o fim de inibir a prática do descuido cada vez mais frequente por parte dos filhos. A reparação é baseada na omissão voluntária que foi prejudicial à vida do idoso. Cláudia Maria da Silva justifica:

A prestação pecuniária, não há como negar, é de extrema importância. Todavia, ela não é suficiente para garantir a vida, a saúde e a dignidade dos pais. Segundo Claudia Maria da Silva, o conviver é basicamente afetivo e, enriquecido com uma convivência mútua, alimenta o corpo, cuida da alma, da moral, do psíquico. (SILVA, 2004, p. 123).

Embora o dinheiro seja essencial para a manutenção da qualidade de vida dos idosos não é o único fator relevante, sabe-se que amar é faculdade, mas cuidar é dever jurídico.

Compartilha-se do entendimento de Paulo Luiz Netto Lobo, no sentido que o princípio da solidariedade, "marco paradigmático que caracteriza a transformação do Estado liberal e individualista em Estado democrático e social” (LOBO, 2007), tem servido para proteger os mais vulneráveis (crianças, adolescentes, idosos, carentes alimentares, etc.), nas relações familiares.

Dessa forma, não obstante a ausência de lei específica no tocante ao abandono afetivo inverso, uma vez violado o dever de cuidado filial-paterno, tem o idoso o direito de exigir a compensação pecuniária, nos termos da legislação geral da responsabilidade civil vigente no Brasil. 


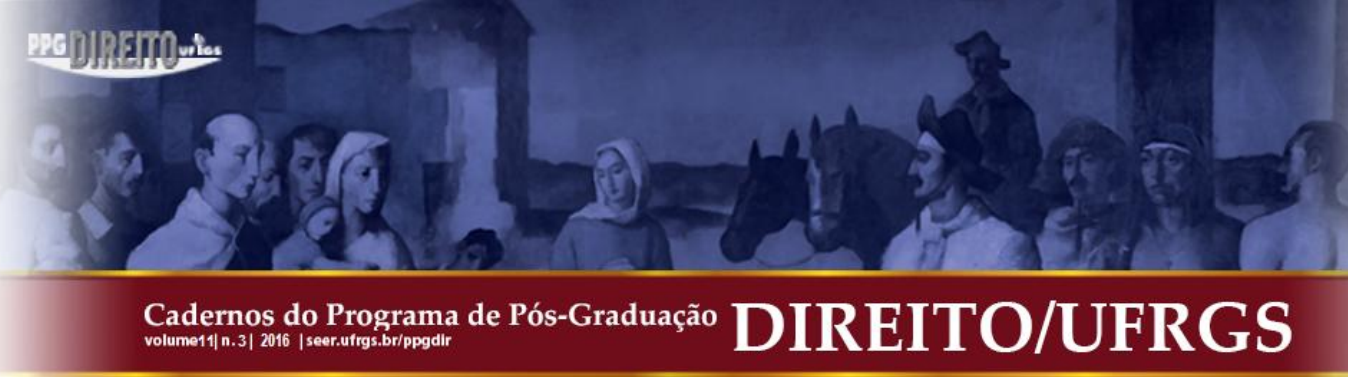

\section{CONSIDERAÇÕES FINAIS}

O processo de envelhecimento não é um fato contemporâneo, ao contrário, vem acompanhando a sociedade desde os seus primórdios. Como consequência, em cada desenvolvimento temporal o fenômeno é visto e vivenciado de determinada maneira, sempre se adequando ao momento social.

Ocorre que o envelhecimento, inerente a todo e qualquer ser humano, cresceu gradualmente e alterou a realidade brasileira, que passou a possuir uma população idosa numerosa, contudo, sem o respaldo de políticas públicas para enfrentar a situação. Erroneamente, teve-se em mente que tal fenômeno se dava apenas em função da idade, descurando-se que se trata de um processo multifatorial, o qual não pode ser submetido a padronizações e estereótipos.

O crescimento populacional dos idosos no cenário mundial é evidente, o processo de longevidade está ocorrendo, entretanto, o Estado, a família e a sociedade não se mostram preparadas para oferecer uma qualidade de vida ao idoso, atrelada o acesso a saúde, educação, cultura e, acima de tudo, cuidado por parte dos filhos.

Atualmente, embora existam garantias constitucionais específicas no campo das políticas destinadas ao público idoso, veem-se, cada vez mais, idosos abandonados por suas próprias famílias, acesso a saúde precário, muitas das vezes somente os de classe alta são atendidos, despreparo educacional para que se atendam as necessidades do idoso, conforme a sua realidade e a desoportunização no mercado de trabalho em função da idade. Nos países subdesenvolvidos, em que a vida do idoso é marcada por baixa qualidade de vida, de consumo, de produtividade e elevadas taxas de miséria e concentração de renda.

Quanto às garantias constitucionais, consideradas necessárias para fazer valer os direitos dos idosos, que, na verdade, deveriam ser automáticos, em face da boa-fé e consideração com o próximo, tem-se o dever de prover e cuidar. Tal obrigação existe dos pais para os filhos e dos filhos para os pais, demonstrando, com isso, que o dever de cuidado não é facultativo aos filhos perante os pais idosos. Podendo ser responsabilizada a família, a sociedade e o Estado, pelo seu descumprimento.

É no contexto da família que surge a figura jurídica do Abandono Afetivo Inverso, ou seja, os filhos abandonam seus pais idosos, abstendo-se, de forma negligencial, em relação a 


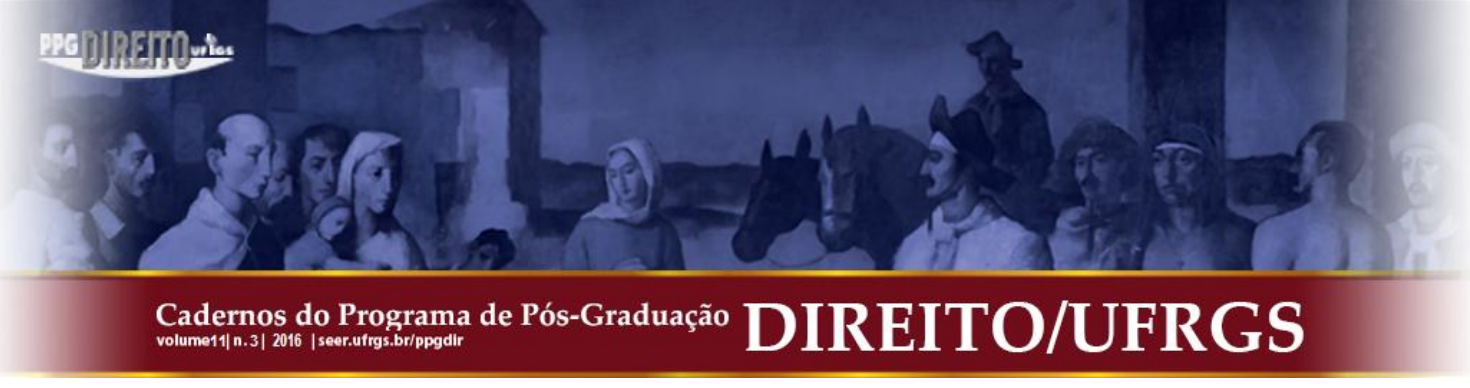

uma ação ou omissão perante o idoso. O viés desse abandono pautado no afeto é a falta de amor, cuidado e assistência por parte desses filhos.

Diante da ausência legislativa quanto ao abandono afetivo inverno, analisou-se a efetividade do Código Civil Brasileiro de 2002, do Estatuto do Idoso - Lei no 10.741/2003, da Lei Orgânica da Assistência Social nº 8.742/1993, em relação aos direitos do idoso, tais como o direito à liberdade, respeito, dignidade, saúde, proteção, atendimento, acesso à justiça, crimes e alimentação. Verificou-se, ainda, a incidência da Política Nacional do Idoso - Lei $n^{\circ}$ 8.842/1994, pela qual emergiram normas com o objetivo de garantir_a participação efetiva, autonomia e a integração do idoso em sociedade.

Diante dessa série legislativa em que o idoso se insere, restou demonstrado que em nosso atual ordenamento jurídico não faltam mecanismos legais que protejam os idosos, e possibilitem o exercício de seus direitos. Contudo a prática de tais mecanismos, não vem sendo exercida de maneira eficaz, observados a quantidade de idosos abandonados pelos filhos e desamparados pelo governo.

É sabido que o afeto não pode ser imposto e tampouco vem explícito em termos legais, todavia, a sua ausência atinge o idoso diretamente e, consequentemente, coloca em evidência o dever de cuidado ignorado e contrário ao Princípio da Dignidade da Pessoa Humana, norteador do Princípio da Igualdade, Princípio da Afetividade e_Princípio da Proteção aos Idosos.

Seguindo a perspectiva de violação do dever de cuidado filial-paterno surge à possibilidade de responsabilização civil, por meio do Abandono Afetivo Inverso, instituto que consubstancia a reparação de danos injustos em face do idoso, com o objetivo de reestruturar o equilíbrio violado, tendo como um dos seus pressupostos de validade o dano, especificamente, o moral. Nesse contexto, discutiu-se a indenização por dano moral, no contexto do Abandono Afetivo Inverso como forma compensatória do sofrimento.

Assim, não obstante a ausência de lei específica no tocante ao abandono afetivo inverso, uma vez violado o dever de cuidado filial-paterno, tem o idoso o direito de exigir a compensação pecuniária, nos termos da legislação geral da responsabilidade civil vigente no Brasil.

Em vista dos argumentos apresentados, conquanto exista o anseio de que os filhos negligentes sejam punidos em face do Abandono Afetivo Inverso, por meio da imposição de 


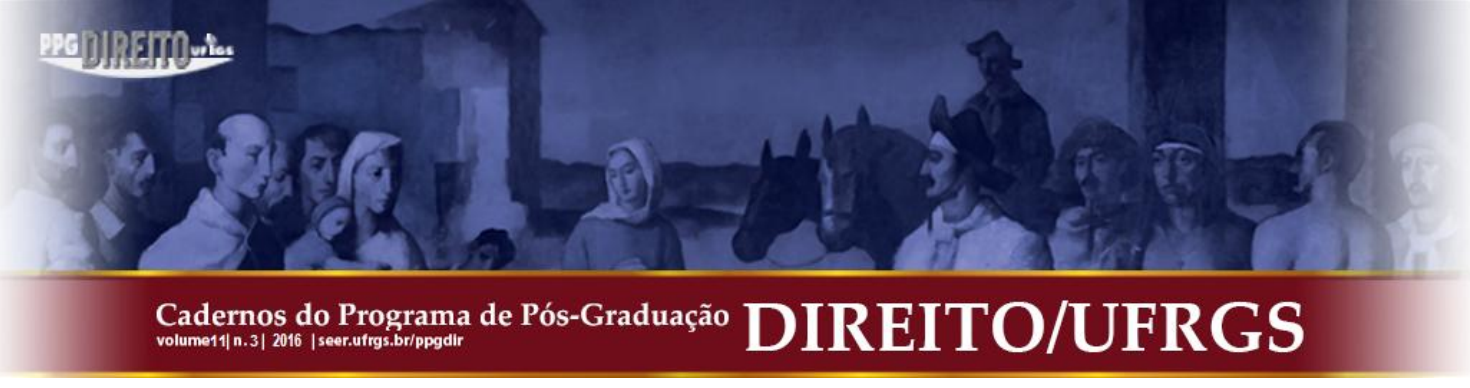

indenização por danos morais, objetiva-se o aspecto preventivo de conscientizar os filhos quanto ao seu papel de cuidador em relação aos seus pais.

Dessa forma, ainda que o amor não possa ser precificado, tem-se que a indenização por danos morais, sem dúvida, emerge como forma de tutelar o dever de cuidado violado pelos filhos, e, concomitantemente, uma ação preventiva com o fim de inibir a prática do descuido cada vez mais frequente por parte dos filhos. Certo é que a base para uma boa qualidade de vida para os idosos está pautada no diálogo, sobretudo, no reencontro transformativo de valores entre pais e filhos.

Assim, se um filho abandonar o pai por mero deleite poderá ser condenado a indenizálo pelo Abandono Afetivo Inverso.

\section{REFERÊNCIAS}

ABANDONO afetivo inverso pode gerar indenização. IBDFAM, 16 jul. 2013. Disponível em:

<http://www.ibdfam.org.br/noticias/5086/+Abandono+afetivo+inverso+pode+gerar+indeniza \%C3\%A7\%C3\%A3o>. Acesso em: 08 maio 2016.

ALLEGRETTI, Fernanda. O melhor lugar do mundo para envelhecer. Veja.com. Caderno Mundo. 13 set. 2014. Disponível em: <http://veja.abril.com.br/noticia/mundo/o-melhor-lugardo-mundo-para-envelhecer>. Acesso em: 12 mar. 2016.

ALMEIDA, Fabiana Souza de. Idosos em instituições asilares e suas representações sobre família. 2005. 103f. Tese (Mestrado). Programa de Pós-graduação. Universidade Federal de Goiás, Jataí, 2005.

ALVES, Sara; MOREIRA, Carmem Félix; NOGUEIRA, Sónia. Relações sociais, estereótipos e envelhecimento. Actas de Gerontologia, Porto, v. 1, n. 1, p. 1-11, 2013.

AMARILHO CB. O executivo-empreendedor, sua aposentadoria e o processo de afastamento do trabalho. Rio de Janeiro: UNATI, 2005

AMORIM, Eveline de Figueiredo Brito. Responsabilidade civil por abandono afetivo: a problemática em torno da compensação. Brasil Escola. Disponível em: $<$ http://monografias.brasilescola.com/direito/responsabilidade-civil-abandonoafetivoproblematica-torno-compensacao.html>. Acesso em: 17 abr. 2016. 


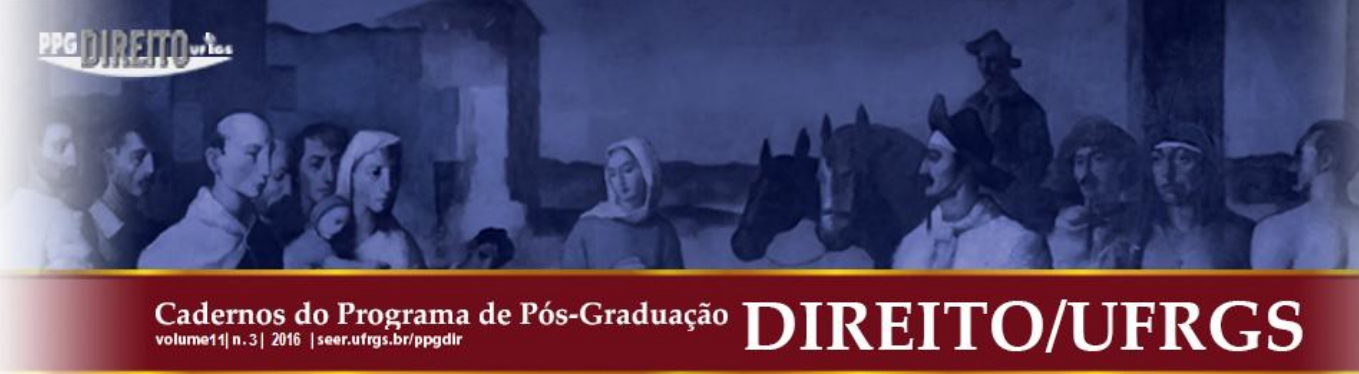

ARAÚJO, Francisco Carlos da Silva. Seguridade social. Revista Jus Navigandi, Teresina, a. 11, n. 1272, 25 dez. 2006. Disponível em: 〈https://jus.com.br/artigos/9311〉. Acesso em: 23 abr. 2016.

AZEVEDO, Álvaro Villaça. Abandono Moral. Jornal do Advogado, OAB/SP, n. 1, 289, dez/2004, p.14.

BERNSTEIN, Tony. Governo canadense oferece moradia especialmente voltada à terceira idade. Portal da $\mathbf{3}^{\mathbf{a}}$ idade. Disponível em: $<$ http://www.portalterceiraidade.org.br/horizontais/noticias_cidadao/anteriores/anterior0149.h tm>. Acesso em: 13 mar. 2016.

BOAS, Marco Antonio Vilas et al. Estatuto do Idoso Comentado. 3. ed. Rio de Janeiro: Forense, 2012.

BORIN, Roseli; ARMELIN, Priscila Kutne. Abandono afetivo do idoso e a responsabilização civil por dano moral. Argumenta, UENP Jacarezinho, no 20, p. 199-221, 2014. Disponível em:

$<$ http://webcache.googleusercontent.com/search?q=cache:elKraOpM9B8J:seer.uenp.edu.br/in dex.php/argumenta/article/download/448/pdf_56+\&cd=1\&hl=pt-BR\&ct=clnk\&gl=br>.

Acesso em: 05 maio 2016.

BOUCINHAS, Ana. A velhice pela história. Amantes da Vida. Disponível em: <http://www.amantesdavida.com.br/a-velhice-pela-historia/>. Acesso em: 16 abr. 2016.

BRAGA, Pérola Melissa Vianna. Curso de direito do idoso. São Paulo: Atlas, 2011

BRASIL. Código Civil (2002). Código Civil. Diário Oficial da União. Brasília, 11 jan. 2002. Disponível em: <http://www.planalto.gov.br/ccivil_03/leis/2002/L10406.htm>. Acesso em 02 abr. 2016.

BRASIL. Código Penal. (1940). Diário Oficial da União. Brasília, 31 dez. 1940. Disponível em: <http://www.planalto.gov.br/ccivil_03/decreto-lei/del2848.htm>. Acesso em: 12 fev. 2016. 


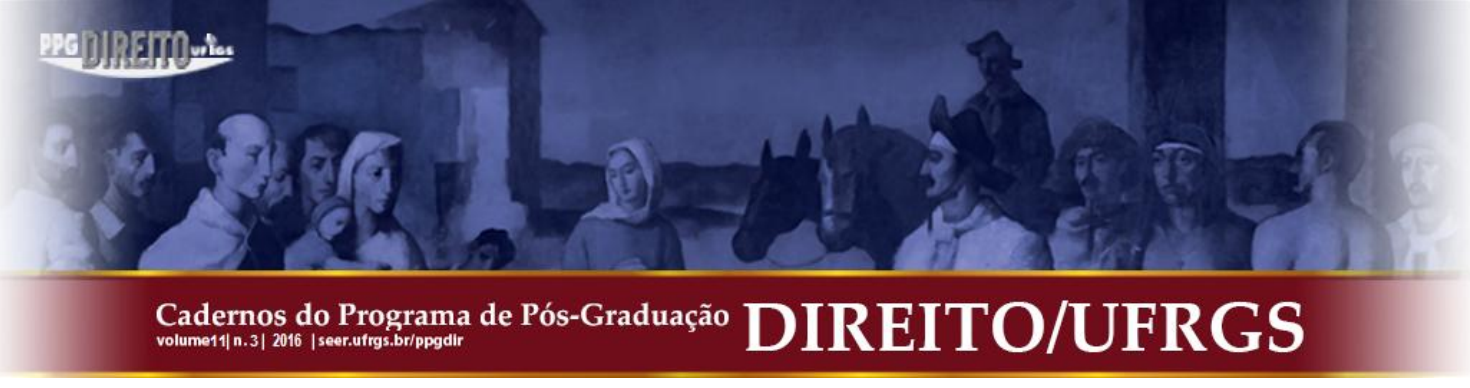

BRASIL. Conselho de Justiça Federal. Enunciado n 50. Diário Oficial da União, Brasília, 26 fev. 2007. Disponível em: <http://www.cjf.jus.br/cjf/corregedoria-da-justicafederal/centro-de-estudos-judiciarios-1/publicacoes-1/outraspublicacoes/enunciados_fonajef.pdf >. Acesso em 16 mar. 2016.

BRASIL. Constituição (1988). Constituição da República Federativa do Brasil. Diário Oficial da União. Brasília, 05 out. 1988. Disponível em: <http://www.planalto.gov.br/ccivil_03/constituicao/constitui\%C3\%A7ao.htm>. Acesso em 02 abr. 2016.

BRASIL. Lei $n^{\circ}$ 8.742, de 7 de dezembro de 1993. Dispõe sobre a organização da Assistência Social e dá outras providências. Diário Oficial da União, Brasília, 08 dez. 1998. Disponível em: <http://www.planalto.gov.br/ccivil_03/leis/L8742.htm>. Acesso em: 16 fev. 2016.

BRASIL. Lei $n^{\circ}$ 8.842, de 04 de janeiro de 1994. Dispõe sobre a política nacional do idoso, cria o Conselho Nacional do Idoso e dá outras providências. Diário Oficial da União, Brasília, 05 jan. $1994 . \quad$ Disponível em: <http://www.planalto.gov.br/ccivil_03/leis/L8842.htm>. Acesso em: 16 fev. 2016.

BRASIL. Lei $\mathrm{n}^{\circ} 10.741$, de $1^{\circ}$ de outubro de 2003. Dispõe sobre o Estatuto do Idoso e dá outras providências. Diário Oficial da União, Brasília, 03 out. 2003. Disponível em: <http://www.planalto.gov.br/ccivil_03/leis/2003/L10.741.htm>. Acesso em: 16 fev. 2016.

BRASIL. Lei $\mathrm{n}^{\circ} 11.340$, de 07 de agosto de 2006. Cria mecanismos para coibir a violência doméstica e familiar contra a mulher, nos termos do $\S 8^{\circ}$ do art. 226 da Constituição Federal, da Convenção sobre a Eliminação de Todas as Formas de Discriminação contra as Mulheres e da Convenção Interamericana para Prevenir, Punir e Erradicar a Violência contra a Mulher; dispõe sobre a criação dos Juizados de Violência Doméstica e Familiar contra a Mulher; altera o Código de Processo Penal, o Código Penal e a Lei de Execução Penal; e dá outras providências. Diário Oficial da União. Brasília, 07 ago. 2006. Disponível em: <http://www.planalto.gov.br/ccivil_03/_ato2004-2006/2006/lei/111340.htm>. Acesso em 16 set. 2014.

CALDAS, C.P. O idoso em seu processo demencial: o impacto na família. In: MINAYO, M.C.S; COIMBRA JR., C. (Org.). Antropologia, Saúde e Envelhecimento. Rio de Janeiro: Editora Fiocruz, 2002.

CARLOS, Roberto. Meu querido, meu velho, meu amigo. 1979. Disponível em: <https://www.vagalume.com.br/roberto-carlos/meu-querido-meu-velho-meu-amigo.html>. Acesso em: 16 maio 2016. 


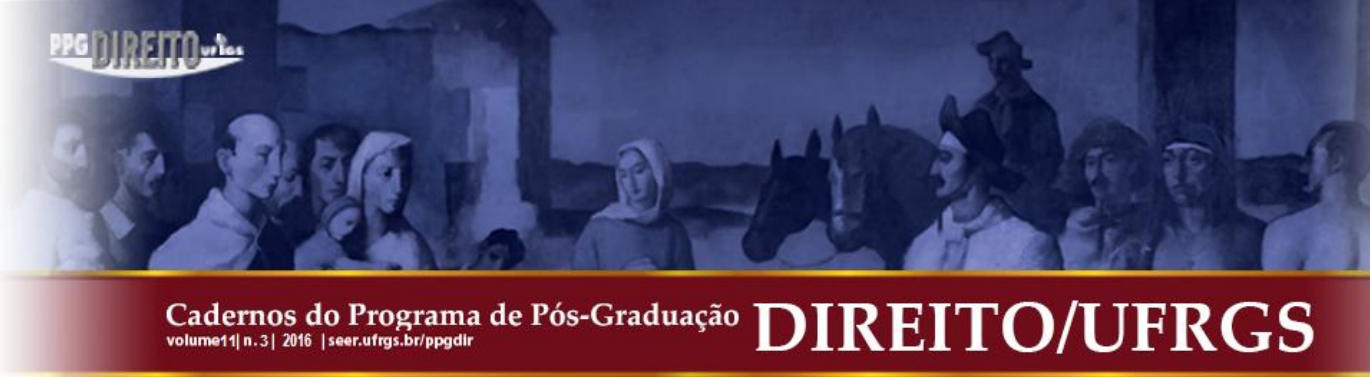

CAVALIERI FILHO, Sergio. Programa de Responsabilidade Civil. $9^{a}$ ed. São Paulo: Atlas, 2010.

CIELO, Patrícia Fortes Lopes Donzele; VAZ, Elizabete Ribeiro de Carvalho. A legislação brasileira e o idoso. Revista CEPPG, v. 2, n. 21, p. 33-46, 2009.

CONTRÁRIO de outros países, Brasil não se preparou para envelhecer, Ao. Revista em Discussão. $\quad$ Ago. 2010. Disponível em: <https://www.senado.gov.br/noticias/Jornal/emdiscussao/revista-em-discussao-edicao-agosto2010/materias/ao-contrario-de-outros-paises-brasil-nao-se-preparou-para-envelhecer.aspx >. Acesso em: 13 mar. 2016.

DIAS, Maria Berenice. ... falando em idosos. 14 fev. 2011. Disponível em: <http://www.mariaberenice.com.br/pt/vocesabia--falando-em-idosos.cont $>$. Acesso em 18 mar. 2016.

DIAS, Maria Berenice. Manual de Direito das Famílias. 4. ed. rev., atual. e ampl. São Paulo. Revista dos tribunais, 2007.

DIAS, Maria Berenice Dias. Manual de Direito das Famílias. 5. ed. rev., atual. e ampl. São Paulo. Revista dos tribunais, 2009.

DINIZ, M. H.; Curso de Direito Civil. São Paulo: Saraiva, 1998.

ECONOMIA exclui idosos. O País. Caderno Economia. 06 dez. 2013. Disponível em: $<$ http://opais.sapo.mz/index.php/economia/38-economia/28047-economia-excluiidosos.html>. Acesso em: 11 mar. 2016.

ENSINO voltado para jovens e adultos muda realidade dos estudantes. Prefeitura de João Pessoa. 02 abr. 13. Disponível em: <http://www.joaopessoa.pb.gov.br/ensino-voltado-parajovens-e-adultos-muda-realidade-dos-estudantes/ > . Acesso em: 16 abr. 2016.

FACHIN, Luiz Edson. Direito de família: elementos críticos à luz do novo código civil brasileiro. 2. ed. Rio de Janeiro: Renovar, 2003.

FALTA de informação dissemina Aids em idosos na Tanzânia. Folha Online, 02 dez. 2004. 


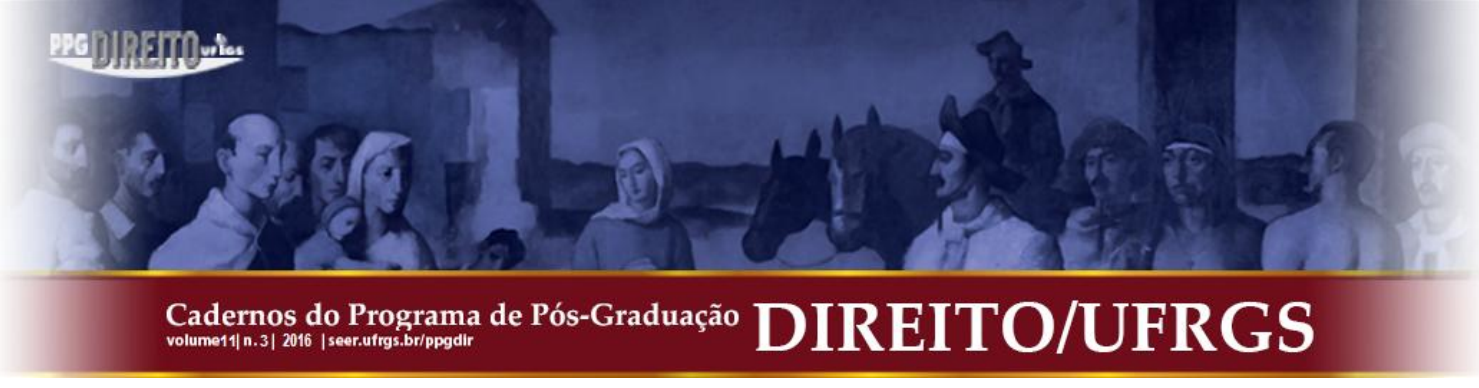

Disponível em: <http://www1.folha.uol.com.br/folha/mundo/ult94u78913.shtml>. Acesso em: 12 mar. 2016.

FERNANDES, Flávio da Silva. As pessoas idosas na legislação brasileira. São Paulo: LTr,1997.

FILHOS têm obrigação de cuidar dos pais idosos, afirma advogada. Fantástico. O Conciliador. 18 maio. 2010. Disponível em: <http://g1.globo.com/fantastico/quadros/oconciliador/noticia/2010/05/filhos-tem-obrigacao-de-cuidar-dos-pais-idosos-afirmaadvogada.html>. Acesso em 23 abr. 2016.

FISCHER, Andréa F. Cresce contaminação por Aids entre idosos. Unimed, 06 dez. 2004. Disponível em: $<$ http://unimed.coop.br/pctr/index.jsp?cd_canal=49146\&cd_secao $=34366 \& c d \_m a t e r i a=2872$ 7>. Acesso em 18 mar. 2016.

GAMA, Guilherme Calmon Nogueira da. Princípios Constitucionais de Direito de Família: guarda compartilhada à luz da Lei 11.698/08, família, criança, adolescente e idoso. São Paulo: Atlas, 2008.

GAMA, Vasco Lopes da. Ser idoso hoje, ser idoso ontem. 20 nov. 2013. Disponível em: <http://comunicar-preciso.blogspot.com.br/2013/11/ser-idoso-hoje-e-ser-idoso-ontem.html>. Acesso em 02 mar. 2016.

GLOBAL AGEWATCH. O que determina o bem-estar socioeconômico de idosos no mundo? Portal do Envelhecimento. 16 set. 2015. Disponível em: <http://www.portaldoenvelhecimento.com/longevidade/item/3776-o-que-determina-o-bemestar-socioeconomico-de-idosos-no-mundo>. Acesso em: 12 mar. 2016.

IDOSOS abandonados pelas famílias encontram solidariedade em abrigo. G1. São Paulo, 06 maio 2014. Disponível em: <http://g1.globo.com/sao-paulo/itapetiningaregiao/noticia/2014/05/idosos-abandonados-pelas-familias-encontram-solidariedade-emabrigo.html>. Acesso em: 06 maio 2016.

INSTITUTO BRASILEIRO DE GEOGRAFIA ESTATÍSTICA. Estatística da População. 2007. Disponível em: <www.ibge.gov.br>. Acesso em: 12 mar. 2016. 


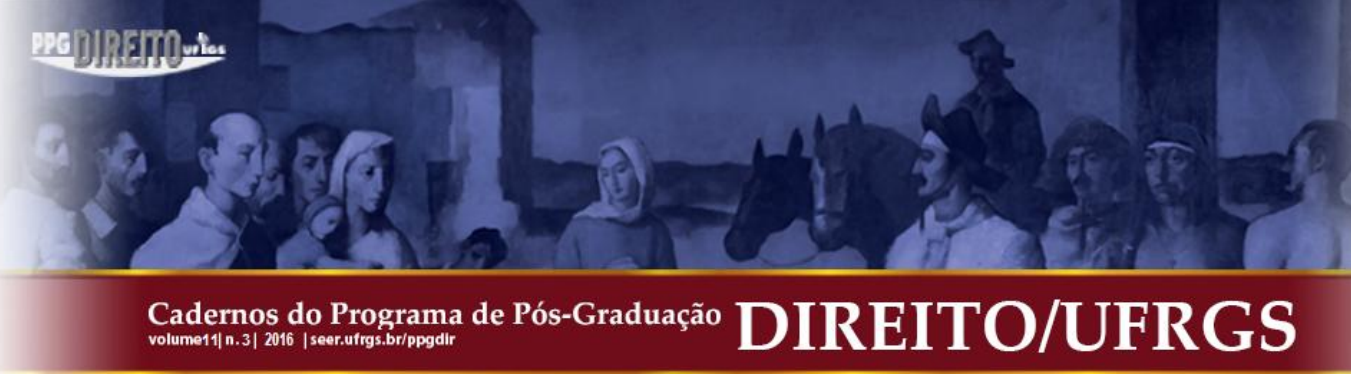

LEMOS et al. Velhice. Disponível em: <http://www.ufrgs.br/epsico/subjetivacao/tempo/velhice-texto.html>. Acesso em: 16 abr. 2016.

LENHARO, Mariana. Mundo terá 1 bilhão de idosos em dez anos e falta estratégia, adverte ONU. Estadão. São Paulo, 02 out. 2012. Caderno Geral. Disponível em: $<$ :http://www.estadao.com.br/noticias/geral,mundo-tera-1-bilhao-de-idosos-em-dez-anos-efalta-estrategia-adverte-onu-imp-,938764>. Acesso em: 24 fev. 2016.

MATIAS, Leonel. Moçambique é um dos piores países do mundo para os idosos. 09 out. 2015. DW. Disponível em: <http://www.dw.com/pt/mo\%C3\%A7ambique-\%C3\%A9-umdos-piores-pa\%C3\%ADses-do-mundo-para-os-idosos/a-18773202>. Acesso em: 14 mar. 2016.

MILHORANCE, Flávia. Grupo de centenários triplica em uma década, mas acesso a saúde ainda é restrito no Brasil. O Globo. 11 jan. 2015. Caderno Saúde. Disponível em: $<$ http://oglobo.globo.com/sociedade/saude/grupo-de-centenarios-triplica-em-uma-decadamas-acesso-saude-ainda-restrito-no-brasil-15019788>. Acesso em: 02 mar. 2016.

MORENO, Denise Gasparini. O Estatuto do idoso. Rio de Janeiro: Forense, 2007.

NERY, Marina. Sociedade - A nova velha geração. Revista Desafios do Desenvolvimento. a. 4, ed. 32, 07 mar. 2007. Disponível em: <http://www.ipea.gov.br/desafios/index.php?option=com_content\&view=article\&id=1143:re portagens-materias\&Itemid=39>. Acesso em 03 mar. 2016 .

NORUEGA é o melhor país para se viver na velhice; Brasil é o $58^{\circ}$. Veja.com. Caderno Mundo. 01 out. 2014. Disponível em: <http://veja.abril.com.br/noticia/mundo/noruegaassume-topo-em-lista-de-melhores-paises-para-se-envelhecer-brasil-cai-para-58>. Acesso em: 12 mar. 2016.

PEREIRA, Rodrigo da Cunha. Princípio da afetividade. In: DIAS, Maria Berenice (Coord.). Diversidade sexual e direito homoafetivo. São Paulo: Revista dos Tribunais, 2011.

PEREIRA. Tânia da Silva. O princípio do melhor interesse: da teoria à prática. In: SOUZA, Jane de. $O$ princípio do melhor interesse aplicado ao direito de família. Disponível em: $<$ http://www.conteudojuridico.com.br/artigo,principio-do-melhor-interesse-da-crianca-e-doadolescente-aplicado-ao-direito-de-familia,31986.html>. Acesso em: 22 fev.16 


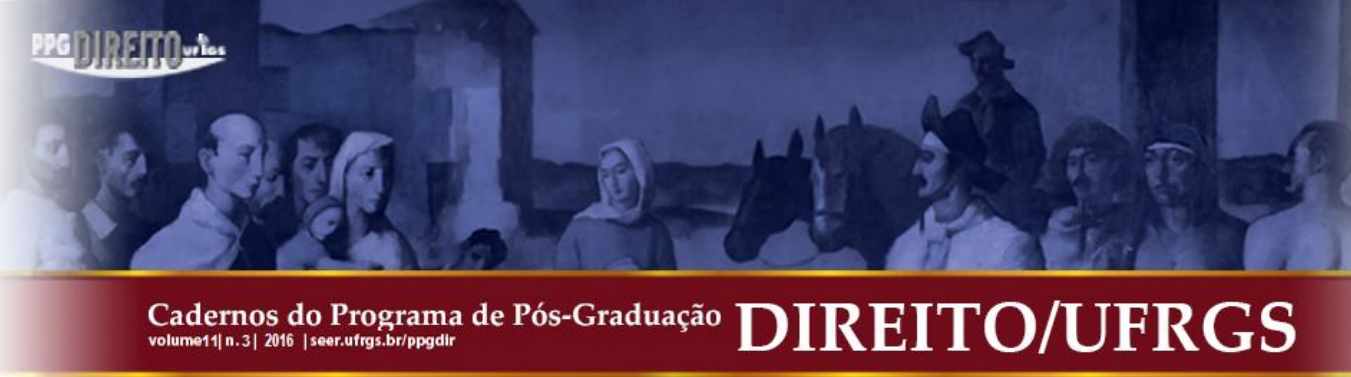

PINTO, Tales do Santos. Era Napoleônica. Mundo Educação. Disponível em? $<$ http://mundoeducacao.bol.uol.com.br/historiageral/era-napoleonica.htm $>$. Acesso em: 22 abr. 2016.

POLÍTICA NACIONAL DO IDOSO: um Brasil para todas as idades, A. Com Ciência, 10 set. $2002 . \quad$ Disponível em: <http://www.comciencia.br/reportagens/envelhecimento/texto/env02.htm>. Acesso em: 12 abr. 2016.

PONTIFÍCIA UNIVERSIDADE CATÓLICA DE MINAS GERAIS. Sistema Integrado de Bibliotecas. P816o Orientações para elaboração de trabalhos técnicos científicos conforme a Associação Brasileira de Normas Técnicas (ABNT). 2. ed. Elaboração: Roziane do Amparo Araújo Michielini. Belo Horizonte, 2016.

PORTO ALEGRE. Tribunal Regional Federal 4. : Recurso Cível no 2007.70.95.014089-0 (PR). Rel. Rony Ferreira. Diário Oficial da Justiça. Porto Alegre, 17 set. 2008. Disponível em:

<http://www2.trf4.jus.br/trf4/controlador.php?acao=consulta_processual_resultado_pesquisa $\&$ selForma=NU\&txtValor=2007.70.95.014089-

$0 \&$ chkMostrarBaixados $=\&$ todasfases $=\&$ todosvalores $=\&$ todaspartes $=\&$ txtDataFase $=01 / 01 / 19$ $70 \&$ selOrigem $=$ TRF $\&$ sistema $=\&$ hdnRefId $=\&$ txtPalavraGerada $=>$. Acesso em: 16 mar.2016.

PRAZERES, Geovana. Saber Envelhecer: Seguido de a Amizade. Bom pra ler. 10 mar. 2008. Disponível em: <http://bompraler.blogspot.com.br/2008/03/saber-envelhecer-seguidode-amizade.html>. Acesso em: 19 abr. 2016.

RODRIGUES, N. C.. Política Nacional do Idoso - Retrospectiva Histórica. In: Estudos Interdiciplinares do Envelhecimento; Porto Alegre, v. 3, p. 149-158.

SANTOS, Maria das Graças Barbosa dos. A proteção do idoso: Brasil x Canadá. Zé Moleza. 22 abr. 2003. Disponível em: <http://www.zemoleza.com.br/trabalhoacademico/humanas/direito/a-protecao-do-idoso-brasil-x-canada/>. Acesso em: 12 mar. 2016.

SARLET, Ingo Wolfgang. Dignidade Da Pessoa Humana e Direitos Fundamentais. 9. ed. Porto Alegre: Livraria do Advogado, 2012.

SAVATIER, Traité de la responsabilité civile em droit français, 2. ed., v. 1.LGDJ, 1951, apud DINIZ, Maria Helena. Curso de direito civil brasileiro: responsabilidade civil, $19^{\mathrm{a}}$ ed. rev. e atualizada de acordo com o novo Código Civil. São Paulo: Saraiva, 2005. 


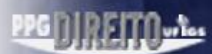

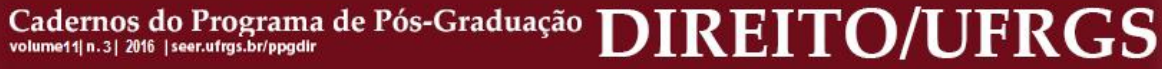

